\title{
Mechanical Properties of Short Polymer Fiber-Reinforced Geopolymer Composites
}

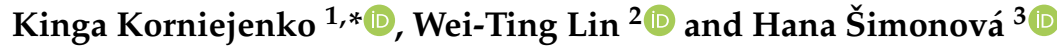 \\ 1 Institute of Material Engineering, Faculty of Material Engineering and Physics, Cracow University of \\ Technology, Jana Pawła II 37, 31-864 Cracow, Poland \\ 2 Department of Civil Engineering, National Ilan University, No.1, Sec. 1, Shennong Rd., Yilan 260, Taiwan; \\ wtlin@niu.edu.tw \\ 3 Faculty of Civil Engineering, Brno University of Technology, Veveři 331/95, 60200 Brno, Czech Republic; \\ simonova.h@vutbr.cz \\ * Correspondence: kinga.korniejenko@mech.pk.edu.pl; Tel.: +48-609-974-988
}

Received: 30 July 2020; Accepted: 31 August 2020; Published: 1 September 2020

\begin{abstract}
The article describes the state of the art in reinforced geopolymers, taking into consideration various types of polymer fiber reinforcements, such as polypropylene, polyethylene, or polylactic acid. The description is focused on the usage of polymer short fibers and the mechanical properties of the geopolymer composites. However, to show a wider research background, numerous references are discussed concerning the selected studies on reinforcing geopolymer composites with long fibers and fabrics. The research method applied in the article is the critical analysis of literature sources, including a comparison of new material with other materials used in similar applications. The results of the research are discussed in a comparative context and the properties of the composites are juxtaposed with the properties of the standard materials used in the construction industry. Potential applications in the construction industry are presented. Moreover, the contemporary research challenges for geopolymer materials reinforced with fibers are presented.
\end{abstract}

Keywords: geopolymer; geopolymer composite; mechanical properties; fiber; polymer fiber; synthetic fiber

\section{Introduction}

Geopolymers are a group of materials that could be defined as inorganic aluminosilicate polymers with specific composition and properties. The geopolymers are obtained in the reaction of polycondensation of ortosilicans (comprising $\mathrm{Si}$ and $\mathrm{Al}$ atoms in their structure) activated usually by $\mathrm{NaOH}$ or $\mathrm{KOH}$ [1]. The geopolymerization process required binding material, and activator [2-4]. The most common applied binding materials are: kaolinite after calcination-metakaolin, calcined clays, industrial waste and by-products (e.g., ashes, slag, waste glass, red mud, mine tailings (different e.g., copper, vanadium), gauges etc.) or other natural and artificial silicoaluminates (e.g., zeolite, pure $\mathrm{Al}_{2} \mathrm{O}_{3}-2 \mathrm{SiO}_{2}$ powder as well as magnesium-containing minerals) [1,4]. As the activators are used usually alkali reactant. It is soluble alkali metal based on sodium or potassium. It includes alkali silicates, hydroxides, carbonates and other addition such as sodium aluminates or cement kiln dust. The most commonly used alkaline reactant solution is a mixture of hydroxides $(\mathrm{NaOH}$ or $\mathrm{KOH})$ and silicates solution $\left(\mathrm{Na}_{2} \mathrm{SiO}_{3}\right.$ or $\left.\mathrm{K}_{2} \mathrm{SiO}_{3}\right)$. Recently, some works have been undertaken on activation by acids, such as phosphate acid [1,4]. That process may be performed at low temperature, but the higher the temperature the better the characteristics of the materials that are obtained [5-7].

Currently, geopolymer composites are the most promising environmentally friendly alternative to traditional cementitious materials, including Portland cement [1,2]. Geopolymers, in contrast to cement 
and alkali-activated based materials, are also characterized by significant durability [3,4]. The main advantages of geopolymers are good compressive strength and good thermal properties (high fire and heat resistance), as well as resistance to corrosive environments [5-7]. The main weakness of these types of composites is brittle cracking, which limits their use in many areas. Therefore, research connected with the possibility of incorporating fibers as reinforcement into a geopolymer matrix is conducted $[2,8]$. Fibers should improve the flexural strength and fracture toughness of these materials $[9,10]$ as well as increase the amount of energy absorbed by geopolymer before damage occurs [3]. In particular, the short fibers, due to their easy fiber dispersion, are an effective way to strengthen geopolymers [11].

The addition of fibers changes the character of the fracture from brittle to more ductile $[2,12]$. The number of cracks in the material is reduced (in particular, the propagation of micro-cracks is reduced) as well as their dimensions - the width of the cracks is limited [12]. Thanks to this, damage caused by brittle cracking is minimized, and it is possible to maintain the cohesiveness of materials for a longer period, which can be critical, especially in emergencies to save people inside the structures $[8,13]$. Therefore, the introduction of fibers into the geopolymer matrix creates an extremely interesting material for construction solutions, which stands out from other solutions currently available on the construction market.

The main goal of the article is to analyze the possibilities of reinforcement of geopolymer composites by different kinds of polymer fibers, compare their properties, and determine the opportunities of using new composite in practical applications, especially in the building industry.

\section{Research Methodology}

The research was focused on mechanical properties of short fiber-reinforced geopolymer composites. The investigation was conducted with scientific articles databases such as ScienceDirect, Scopus, and Google Scholar. It was fixated on the term "geopolymer" as well as similar ones, such as: "inorganic polymer" and "alkali-activated material", taking into consideration the phrase "mechanical properties" and next the keyword "fiber". Also, additional search phrases connected with a particular kind of fiber, exemplary "polypropylene fiber" were applied.

\section{Composites Reinforced with Polymer Fibers}

Synthetic fibers are currently the most commonly used addition to various types of composites. The main aim of the addition of polymer fibers is improving mechanical properties, in particular bending strength $[8,14]$ and reducing the propagation of micro-cracks in the material [8]. Depending on the type of fiber used, other benefits could be achieved, for example, increasing fire resistance [14], a decreasing thermal conductivity coefficient, or other features desirable for a particular application such as decreasing weight of the composites $[8,9,15]$. The disadvantage of the polymer fiber could be used as raw material mainly not renewable resources. These kinds of fiber are usually obtained from limited resources such as crude oil, however, modern technologies allow also extract plastics from renewable raw materials-bio-based polymers. As the raw material, starch or bio-succinic acid are commonly used [16].

\subsection{Aramid}

The research of geopolymer composites with aramid fiber was carried out using a geopolymer matrix based on fly ash and aramid fibers with a length of $30 \mathrm{~mm}$ and a diameter of $0.5 \mathrm{~mm}$ in an amount of $1.0 \%$ by volume [17]. The samples were cured at a high temperature: $85^{\circ} \mathrm{C}$ for $10 \mathrm{~h} \mathrm{[17]}$. The results show increasing the mechanical properties-matrix material reached $70 \mathrm{MPa}$ compressive strength, while composites with fiber addition reached $88.0 \mathrm{MPa}$ [17]. A significant increase in value occurred also for flexural strength, respectively: $10.4 \mathrm{MPa}$ for a composite with $1.0 \%$ fiber content, compared to the value of 7.1 MPa obtained for a matrix material and tensile strength-an increase from 3.1 MPa for matrix material up to $7.7 \mathrm{MPa}$ for composite [17]. The short aramid fibers seem to be 
a promising reinforcement for the geopolymer matrix, however, this kind of fiber is usually applied as long fibers or textiles [18]. There is a problem with the availability of aramid short fibers in the market.

\subsection{Polyacrylonitrile (PAN)}

Polyacrylonitrile (PAN) fibers were investigated in a geopolymer matrix made of metakaolin and slag. The PAN fibers had a length of $6 \mathrm{~mm}$ and a diameter of $12 \mu \mathrm{m}$. Fiber additives were used in the following weight proportions: $0.0 \%, 0.4 \%, 0.8 \%$, and $1.2 \%$ [19]. The best results were achieved for the composite with $0.8 \%$ PAN fiber addition. It was, respectively, $99.84 \mathrm{MPa}$ for compressive strength, compared to the result of about $80 \mathrm{MPa}$ obtained for the matrix material and $13.76 \mathrm{MPa}$ for flexural strength, compared to the result of about $4 \mathrm{MPa}$ obtained for the matrix material [19]. However, increasing the flexural strength is significant and gives a perspective for the application of this composite in civil engineering, there is a lack of information about further research for the composites with PAN fibers.

\subsection{Polyamide (PA)}

Research with polyamide (PA) fibers was conducted based on a geopolymer matrix composed of metakaolin, slag from the Bolu Cement Company in Turkey, sand, and colemanite waste (borate mineral) from the Eti Mining Company in Turkey [20]. The PA fibers were added in the following proportion: $0.4 \%, 0.8 \%$, and $1.2 \%$ by volume. The fiber dimensions were: diameter $55 \mu \mathrm{m}$ and length $10 \mathrm{~mm}$. The studies were conducted after 3, 7, and 28 days after samples production [20]. Research results show the increase of the mechanical properties of composites over time. In the case of compressive strength, after 28 days, the best results were obtained for a sample containing $0.8 \%$ volume PA fibers: $62 \mathrm{MPa}$, compared to the value of the sample without reinforcement of 61.6 $\mathrm{MPa}$. The best result of flexural strength was found for composites with a 1.2\% PA fiber content: 11.4 MPa, compared to the matrix material of 8.8 MPa [20]. The results obtained were referred to other types of fillings - basalt, polyolefin, and PVA fibers. Composites with the addition of PA fibers had worse mechanical properties than those with the addition of basalt fibers or PVA, but they had better properties than composites with polyolefin fibers [20].

\subsection{Polyethylene (PE)}

Polyethylene (PE) fibers are in third place of the most investigated polymer fibers in the geopolymer matrix (after PP and PVA). Nematollahi et al. [21] made comparative studies on the addition of PE and PVA fibers to geopolymer matrix composed of fly ash and slag [21]. PVA fibers had the following dimensions: length $8 \mathrm{~mm}$ and diameter $40 \mu \mathrm{m}$, and PE fibers: length $12 \mathrm{~mm}$ and diameter $12 \mu \mathrm{m}$. Composites were formed with $2 \%$ by volume fiber addition [21]. The mechanical properties were investigated after 28 days. The results of the tests showed a reduction in compressive strength as a result of the addition of PE fibers and a slight increase in this property for PVA fibers. The compressive strength was 48.6 MPa for the geopolymer matrix, 44.3 MPa for the composite with PE fibers, and 48.7 MPa for the composite with PVA fibers [21]. In the case of tensile strength, the composites with PVA fibers reached 4.6 $\mathrm{MPa}$, while with the addition of PE it was 4.2 $\mathrm{MPa}$. There is lack of information about tensile strength for the matrix material [21].

The PE fibers (length $12 \mathrm{~mm}$ and diameter $12 \mu \mathrm{m}$ ) were also tested as an addition for the geopolymer in amount: $0.0,0.5,1,1.5$ and $2.0 \%$ by weight [22] and with a content of $0.0 \%, 0.5 \%, 0.75 \%, 1.0 \%, 1.5 \%$ by weight [23]. The matrix components were mainly products from the Gladstone power plant in Queensland, Australia [22,23] — fly ash and slag. Samples were tested after 28 days. In both articles, results are very similar. The decrease of compressive strength of the composites was noted. However, in both experiments, fiber composites behaved slightly differently. In the first experiment, the highest value was obtained for the matrix material-about $80 \mathrm{MPa}$, for subsequent samples this value decreased with the increasing amount of the fibers. The value was above $70 \mathrm{MPa}$ for the $0.5 \% \mathrm{PE}$ fibers addition and only about $30 \mathrm{MPa}$ for $2.0 \%$ fibers addition [22]. In the second experiment, the highest value was 
obtained also for the control sample, matrix material, of 56.7 MPa. For composites with PE fibers, these values were lower and increasing with the fiber content: $0.5 \%-28.4 \mathrm{MPa}, 0.75 \%-35.0 \mathrm{MPa}$, $1.0 \%-44 \mathrm{MPa}$ and $1.5 \%-45 \mathrm{MPa}$ [22]. The best results for the bending strength were achieved for about $0.75-1.0 \%$ of the addition of PE fibers [22,23].

Other research was provided for composites reinforced by PE fibers- $-1.75 \%$ by weight. The fibers have dimensions: length $18 \mathrm{~mm}$ and diameter $12 \mu \mathrm{m}$ [24]. The matrix was based on slag with different proportions of water and activator. The authors obtained the results of compressive strength between 36.3 and $54.8 \mathrm{MPa}$ and flexural strength between 5.1 and $13.1 \mathrm{MPa}$, however, in this research, there is a lack of information about mechanical properties of plain samples [24].

\subsection{Polyethylene Terephthalate (PET)}

Polyethylene terephthalate (PET) fibers were investigated in a geopolymer matrix made of fly ash and slag and compared with composites reinforced by polypropylene (PP) fibers. The PET fibers had a length of $12 \mathrm{~mm}$ and a diameter of $38 \mu \mathrm{m}$ and the PP fibers had a length between 12 and $19 \mathrm{~mm}$ and a diameter of $22 \mu \mathrm{m}$. Fiber additives were used in the following volume proportions: 1.0 and $1.5 \%$ [25]. The results show that irrespective of fiber types the compressive strength of all composites decreased due to an increase in fiber volume from $1 \%$ to $1.5 \%$. The flexural strength of PET fiber reinforced geopolymer was increased due to an increase in PET fiber volume fractions from $1 \%$ to $1.5 \%$. Additionally, PET fiber exhibit higher tensile strength than their counterpart PP fiber reinforced composites. There is a lack of comparison with a plain matrix in [25].

\subsection{Polypropylene (PP)}

Polypropylene (PP) was originally used as reinforcement for concretes, improving their flexural strength. Therefore, attempts were also made to use it to reinforce composites based on geopolymers. PP fibers were one of the first fibers added to geopolymers [26,27]. PP fibers have been added to both fly ash and metakaolin geopolymers. The first studies in this field were carried out based on a matrix made of slag and fly ash with $0.5 \%$ and $1 \%$ by volume of the fibers [26]. The research results showed that too low fiber content does not have a positive effect on the properties of geopolymer concrete.

Further studies with the use of PP fibers showed a positive influence on the mechanical properties of geopolymer composites [28]. Zhang et al. tested geopolymer composites made with the metakaolin (kaolin calcined at $900{ }^{\circ} \mathrm{C}$ for $6 \mathrm{~h}$ ) and the short PP fibers (diameter: $10 \mu \mathrm{m}$ and length: $3 \mathrm{~mm}$ ) [28]. The fibers were added in the amount of $0.0 \%, 0.25 \%, 0.5 \%$, and $0.75 \%$ by weight. The samples were tested after 1 day and 3 days. The results showed an increase in compressive strength and flexural strength depending on the addition of fiber. The best results for compressive strength were obtained for $0.5 \%$ fiber content, which was, respectively: $54.7 \mathrm{MPa}$ after 1 day and $52.3 \mathrm{MPa}$ after 3 days. For reference samples without fiber content, these results were respectively: $32.6 \mathrm{MPa}$ and $41.5 \mathrm{MPa}$. The best results for flexural strength were obtained for the sample with the addition of $0.75 \%$ PP fiber, it was $10 \mathrm{MPa}$ after 1 day and 9.4 MPa after 3 days. For reference samples, these values were $5.0 \mathrm{MPa}$ and 5.5 MPa. The authors do not explain the decreasing of mechanical properties over time for samples with PP fiber [28].

Also, studies with fly ash-based geopolymers have shown the positive effect of PP fibers on the mechanical properties of the composites. PP fibers were added to the composites based on class F fly ash in an amount of $0.05 \%$ and $0.15 \%$ by weight [29]. The research showed an increase in the mechanical properties over time and the achievement of higher compressive strength values (over $30 \mathrm{MPa}$ ) for composites with $0.15 \%$ PP fiber addition compared to the base material [29]. The beneficial effect of PP fibers on the properties of geopolymer composites based on fly ash class F was also confirmed [30]. Short PP fibers for dedicated concrete in the amount of $5 \%, 10 \%, 15 \%$, and $20 \%$ by volume were used as reinforcement for geopolymers. The flexural strength was investigated. The best results were obtained for $15 \%$ and $20 \%$ by volume of fibers, it was respectively $7.6 \mathrm{MPa}$ and $7.9 \mathrm{MPa}$ compared to the samples 
with 5\% PP content, for which only 2.1 MPa was obtained [30]. The tests also confirmed the good cohesion of the fibers with the matrix [30].

Fly ash class $\mathrm{F}$ ashes from Malayan Cement Bhd of Malaysia were used for manufacturing the composites with $0.5 \%, 1 \%, 2 \%, 3 \%, 4 \%$, and $5 \%$ by volume of PP short fibers. The studies were conducted after $2,7,14,28,56$ days [31,32]. The results obtained were presented in a graphic form, which does not allow giving precise values for mechanical properties. However, the results show that the addition of the fibers increases the flexural strength and cause a decrease in the compressive strength [31,32]. In the case of flexural strength, a positive effect was noticed for composites with the addition of more than $1 \%$ of PP fibers (for $0.5 \%$ there was a decrease in the value compared to the matrix material) on the results obtained in the early period of material curing-up to about 2 weeks. After this period, the bending strength of the matrix material increased, and it stabilized for composites with $1 \%, 2 \%$, and $3 \%$ fiber addition, but its values were lower than for the plain material. The best results were obtained for $4 \%$ and $5 \%$ fiber addition. Even after 56 days, they were higher than for the matrix material itself and exceeded $10 \mathrm{MPa}[31,32]$. The compressive strength was tested after 7 days, the properties of the composites with various fiber additions were similar to the value obtained for the matrix material itself and had about $30 \mathrm{MPa}$. After this time (the tests were carried out for 56 days), the strength of the matrix material itself increased to about $60 \mathrm{MPa}$, and for composites with fibers, it changed only slightly-up to about $35 \mathrm{MPa}$ [31,32].

Tests of composites with short PP fibers were also conducted based on a matrix composed of class F fly ash from the Catalagzi/Zonguldak power plant in Turkey and slag from the Bolu cement plant [33]. PP fibers were added to the matrix in a volumetric ratio: $0.4 \%, 0.8 \%$ and $1.2 \%$; fibers had dimensions: $0.0075 \mathrm{~mm}$ in diameter and $12 \mathrm{~mm}$ in length [33]. The composite was heated at $80^{\circ} \mathrm{C}$ for $24 \mathrm{~h}$. The samples were tested after 7 and 28 days [33]. The test results showed slight changes in strength compared to the control samples (without fibers) for both compressive strength and bending strength. The samples did not show a significant increase in the strength values over time [33]. The best results were obtained for the compressive strength after 28 days, it was about $61 \mathrm{MPa}$ for the sample with $0.4 \%$ PP fiber content, compared to the strength of $60.5 \mathrm{MPa}$ obtained by the reference samples. The flexural strength for the samples with fiber reinforcement was: $9.7 \mathrm{MPa}$, compared to $8.5 \mathrm{MPa}$ for the control sample [33].

The mechanical properties of geopolymers with the addition of PP fibers were also tested based on a matrix from class $C$ fly ash, slag after steel processing, and sand [34]. The PP fibers added to the composites had the following dimensions: diameter: 18-30 $\mu \mathrm{m}$ and length: $12 \mathrm{~mm}$; they were added in $0.0 \%, 0.1 \%, 0.2 \%, 0.3 \%$ and $0.4 \%$ by volume. The samples were tested after 3,7 , and 28 days [34]. The compressive strength increased over time for all composites, after 3 days it was about $12 \mathrm{MPa}$, after 7 days about $22 \mathrm{MPa}$, and after 28 days above $35 \mathrm{MPa}$. All composites achieved higher values than the matrix material. The highest values were achieved for $0.2 \%$ by volume of PP fiber addition, it was $39.0 \mathrm{MPa}$, compared to about $35 \mathrm{MPa}$ for the matrix material. The compressive strength values of composites reinforced by PP fiber was compared with basalt and steel reinforcement. It was lower than for composites reinforced with basalt fiber but slightly higher than for steel reinforcement [34]. The increase in flexural strength was also observed over time. This value after 3 days was about $3 \mathrm{MPa}$, after 7 days about $3.5 \mathrm{MPa}$, and after 28 days about $6.5 \mathrm{MPa}$. Composites with $0.1 \%, 0.2 \%$, and $0.3 \%$ additions achieved higher values than the matrix material, while the material with $0.4 \%$ PP fibers was slightly lower. The highest values were achieved for $0.2 \%$ of PP fiber addition; it was $7.0 \mathrm{MPa}$, compared to about 6.5 MPa for the matrix material. The values obtained were slightly lower than for materials with basalt or steel reinforcement [34].

The influence of the PP fiber type on the mechanical properties was also investigated [35]. The tests were carried out on a matrix made of sand and slag with the use of two types of PP fibers. The fibers had different properties and methods of production. The first, defined as "split fiber", was created by cutting tapes of split yarns and had the dimensions of $20 \mu \mathrm{m}$ in diameter and $12 \mathrm{~mm}$ in length. The other fiber, called "multi-fiber", was a conventional spun fiber (there were aggregations of fiber 
in the material) with dimensions: $38 \mu \mathrm{m}$ in diameter and $20 \mathrm{~mm}$ in length. Fibers were added to the composite in an amount of $2 \%$ by volume. The samples were investigated after 7 and 28 days [35]. The flexural strength for both fibers used in the tests increased. It was approx. $8 \mathrm{MPa}$ for matrix material up to $31 \mathrm{MPa}$ for "split fiber" and about $32 \mathrm{MPa}$ for "multi-fiber" - after 28 days. The compressive strength after 28 days was about $80 \mathrm{MPa}$ for reference samples, about $75 \mathrm{MPa}$ for "split fibers" and almost $100 \mathrm{MPa}$ for "multi-fibers" [35].

The other research studies conducted in this field show slight changes in the mechanical properties of materials, both for composites based on fly ash as well as slag with various fiber additives [36,37]. The interesting phenomenon in the case of the addition of PP fibers is the decrease of compressive strength over time, occurring in about half of the presented research works in this field. This phenomenon is mostly explained by the authors by the presence of additional spaces between the reinforcement and the matrix in the matrix material curing process [31-33,35,37]. Zhu et al. confirmed that if the amount of fibers in composites is properly selected, both compressive and flexural strength should increase [38].

Zhu et al. carried out research with the usage of fly ash-based geopolymers. The samples were

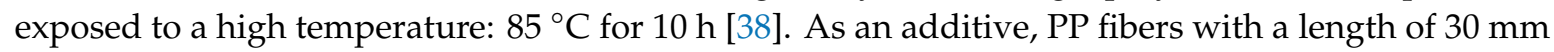
and a diameter of $1 \mathrm{~mm}$ were used in the amount of $1.5 \%$ by volume [38]. The results show the improvement of mechanical properties. The compressive strength of the matrix was $70 \mathrm{MPa}$, and the composites with the addition of fibers was 91.7 MPa [38]. The values for the flexural strength were respectively 8.4 MPa for the composite, compared to 7.1 $\mathrm{MPa}$ for the matrix material [38]. The research also included tensile strength tests. There was an improvement from $3.1 \mathrm{MPa}$ for the matrix material to 6.4 MPa for the composite with PP fibers [38].

This type of composite also has significant resistance to cracking at high temperatures, which allows it to be used as fireproof barriers in construction $[9,39]$. This kind of material could be used as lightweight construction and isolation materials [39]. Wang et al. have studied foamed geopolymers reinforced by PP fibers [39]. As a raw material, the fly ash from the Chinese coal mine company has been used (Class II according to the Chinse Standard of GB/T1596-2017). The fibers have a diameter of $0.017 \mathrm{~mm}$ and length between 3 and $19 \mathrm{~mm}$. The fibers were added in $0.5 \%, 1.0 \%, 1.5 \%$ and $2.0 \%$. The best results were achieved for $0.5 \%$ PP fiber addition. The results show a significant improvement in the composition with PP fibers. The compressive strength of fiber reinforced composites with fiber lengths of $3 \mathrm{~mm}, 6 \mathrm{~mm}, 9 \mathrm{~mm}, 12 \mathrm{~mm}$, and $19 \mathrm{~mm}$ was increased by 57\%, 46\%, 57\%, 71\%, and 6\% respectively compared to the reference samples [39].

The innovative approach to fiber-reinforced geopolymers is also presented by Nematollahi et al. [40, 41]. The raw materials for the geopolymer matrix were: fly ash, micron-scale silica sand. The PP fibers ranging between $0.25 \%$ and $1.00 \%$ by volume were added to a geopolymer mixture [40]. The fibers have a diameter of $11.2 \mu \mathrm{m}$ and length of $6 \mathrm{~mm}$. The use of fiber dosages more than $0.5 \%$ by volume caused the deflection-hardening behavior of the 3D-printed geopolymers and higher fracture energy in comparison to specimens without fiber or with lower fiber content. The best results were achieved by $0.25 \%$. The received results were strongly correlated with the direction of the force [40].

The behavior of PP fibers was investigated also in boroaluminosilicate geopolymers and compared to conventional aluminosilicate binders [42]. The PP fibers were added in $0.5 \%$ and $1.0 \%$ by weight (length: $19 \mathrm{~mm}$, diameter: $40 \mu \mathrm{m}$ ). The results show the flexural strength of aluminosilicate geopolymer as well as boroaluminosilicate declines. The main advantage of adding the PP fibers was an improvement of about $0.8 \mathrm{~J}$ surge in the toughness [42].

Chen et al. modified metakaolin-based geopolymers by polyacrylic emulsion (PAA) and PP fibers [43]. The PP fibers have a diameter of $40 \mu \mathrm{m}$ and length of $8 \mathrm{~mm}$. The fibers were of dosages $0.1 \%, 0.2 \%, 0.3 \%$ and $0.4 \%$ relative to the total volume [43]. The best results for the PP fibers were achieved by $0.2 \%$ and $0.3 \%$ volume addition. The compressive strength increases from ca. $48 \mathrm{MPa}$ for the matrix to ca. $49 \mathrm{MPa}$ for the composite with $0.2 \% \mathrm{PP}$ fibers and almost $53 \mathrm{MPa}$ after the modification by PAA (the base value for modified samples by PP was the same as for plain matrix). For the $0.3 \% \mathrm{PP}$ 
fibers, the compressive strength for the matrix material decreased below $45 \mathrm{MPa}$, but for the material with PAA modification increased up to $55 \mathrm{MPa}$. The flexural strength for the plain matrix was ca. 5.6 MPa after PAA modification it increased to $7 \mathrm{MPa}$. For both materials, the PP fibers addition in $0.2 \%$ caused improvement of flexural strength up to $6.9 \mathrm{MPa}$ and 9.2 $\mathrm{MPa}$, respectively [43].

The different types of PP fibers have been tested also by Noushini et al. [44]. They added three types of PP fibers: 18, 19, and $51 \mathrm{~mm}$ length with a volume fraction of $0.5 \%$ to a geopolymer based on fly ash and slag. The results show a decrease in compressive strength for all types of fiber. After 28 days for the reference samples, the compressive strength was $50.4 \mathrm{MPa}$, and samples with PP fibers were between 46.7 and 47.3 $\mathrm{MPa}$ [44]. The authors investigated also tensile strength that slightly increases from 4.1 MPa for the matrix to 4.3 MPa for the composite with $19 \mathrm{~mm}$ PP fibers [44].

The trials were also provided on a geopolymer based on zeolitic tuff and fine aggregates—river sand reinforced by PP fibers (length 12-19 $\mathrm{mm}$ ) [45]. The PP fibers were implemented in $0.5 \%$ and $1.0 \%$ by weight. The compressive strength was investigated, however, received results are very low and required further works. The best results were achieved for $0.5 \%$ fiber additions; it was barely 4.6 MPa [45].

Much higher results for mechanical properties were achieved by Pham et al. [46]. Two kinds of PP fibers (the length of 10 and $15 \mathrm{~mm}$, the diameter of $50 \mu \mathrm{m}$ ) were added in amount $0.5,1.0$, and 1.5\% by volume to geopolymer matrix based on fly ash with aggregates [46]. The results show improvement compressive strengths as well as flexural strengths for both types of PP fibers. The better results were achieved for shorter PP fibers of $10 \mathrm{~mm}$ lengths. The best results for compressive strength was for 0.5 vol. \% PP fibers achieved 43.3 MPa, compared with 32.0 MPa for a plain matrix [46]. The flexural strength had a higher value for $1.5 \%$ vol. PP fibers addition achieved almost $8 \mathrm{MPa}$, compared with 5.9 MPa for the material without reinforcement [46]. The authors also compared results for PP fibers with steel fibers. The slightly better mechanical properties were noted for the composites reinforced by steel fibers [46]. These works also show the possibility of computer modeling the predicted values for this kind of composite [46].

The metakaolin based geopolymers with aggregates were reinforced by PP fibers of length $6 \mathrm{~mm}$ and diameter $20 \mu \mathrm{m}$ [47]. The PP fibers were added to the mixture at $0.3 \%, 0.5 \%$, and $1.0 \%$ by mass. The results show a lack of changes in compressive strength-the strength of the control sample was $52.6 \mathrm{MPa}$ which increased by less than $1.0 \%$ upon adding $1 \%$ PP fibers and increasing the flexural strength. The flexural strength of the control sample was 3.6 MPa which improved to 3.8, 4.2, and $4.9 \mathrm{MPa}$ when $0.3 \%, 0.5 \%$, and $1.0 \%$ PP fibers were added [47].

The decrease of compressive strength of the geopolymer composites after PP fibers addition was also observed by Yuan et al. [48]. The matrix was made from fly ash with different slag addition. The PP fibers (length $12 \mathrm{~mm}$ and diameter $40 \mu \mathrm{m}$ ) were added to the mixture in an amount of $0.15 \%$, $0.30 \%$, and $0.45 \%$ by volume [48]. The compressive strength decreased from $80 \mathrm{MPa}$ for the matrix to 74.8, 72.1, and 46.3 $\mathrm{MPa}$ for the composites with fibers [48].

Among the various types of fiber, PP fiber is the most commonly used for thermal insulation purposes and as lightweight materials [49-51]. The fibers in the geopolymer matrix are also resistant to high temperatures up to $900{ }^{\circ} \mathrm{C}$ [52]. Other reasons for the greater usage of PP fibers also include economical advantage and excellent resistance to environmental aggressiveness $[39,52]$.

\subsection{Polyvinyl Alcohol (PVA)}

A large amount of research has also been conducted with a polyvinyl alcohol (PVA) fiber-reinforced geopolymer matrix. These tests compared composites with PP fibers and PVA fibers have been conducted [33]. The matrix based on fly ash class F from the Catalagzi/Zonguldak power plant in Turkey and slag from the Bolu cement plant were used for this research. PVA fibers were added to the matrix in $0.4 \%, 0.8 \%$, and $1.2 \%$ by vol. (fibers dimensions: $0.04 \mathrm{~mm}$ in diameter and $8 \mathrm{~mm}$ in length). The composite was cured at $80{ }^{\circ} \mathrm{C}$ for $24 \mathrm{~h}$. The samples were tested after 7 and 28 days [33]. The test results show an increase in the mechanical properties of the samples with fibers compared to 
the control samples (without the fibers content) [33]. The best results were for compressive strength for composites with $1.2 \%$ fibers content of $63.1 \mathrm{MPa}$, compared to 60.5 obtained for reference samples and strength bending of $11.8 \mathrm{MPa}$, compared to $8.5 \mathrm{MPa}$ for the control samples [33].

Tests with PVA fibers were also carried out based on a geopolymer matrix composed of metakaolin, slag from the Bolu Cement Company in Turkey, sand, and colemanite waste (a mineral from the borate group) from the Eti Mining Company mine in Turkey [20]. The tests were carried out with $0.4 \%$, $0.8 \%$, and $1.2 \%$ by volume of PVA fibers. The added fibers had a diameter of $39 \mu \mathrm{m}$ and a length of $8 \mathrm{~mm}$ [20]. The research results show an increase in the compressive strength; the best results were obtained for the samples containing $1.5 \%$ by volume of PVA fibers of $66.2 \mathrm{MPa}$, compared to the value of the sample without reinforcement of $61.6 \mathrm{MPa}$. The highest value for flexural strength was achieved for the composite with $1.2 \%$ fiber content of almost $12.2 \mathrm{MPa}$, compared to the matrix material of about $8.8 \mathrm{MPa}$ (according to the data presented in the diagram, which they are consistent with the data found elsewhere in the article, according to which the strength reached almost $12 \mathrm{MPa}$ ) [20]. The composite results were compared with basalt, polyolefin, and PA composites. The composites with PVA fibers had the best compressive strength and were second (after the composites with basalt fibers in terms of flexural strength) [20].

Composites with $0.5 \%$ and $1 \%$ by volume of PVA fibers (diameter of $38 \mu \mathrm{m}$ and length of $8 \mathrm{~mm}$ ) were investigated in a geopolymer matrix based on fly ash from the Eraring power plant in the New South Wales region of Australia [53]. The research was carried out both for the traditional matrix and for the foamed geopolymers [53]. The compressive strength for the non-foamed geopolymers was about $20 \mathrm{MPa}$. In the case of foamed geopolymers (foamed agent- $-\mathrm{H}_{2} \mathrm{O}_{2}$ ) the addition of PVA fibers increased the compressive strength by about $5 \mathrm{MPa}$ compared to the plain matrix [53]. The results of the flexural strength for the non-foamed matrix show its increase with an increasing amount of fibers in the composite to about $13 \mathrm{MPa}$ for $1 \%$ fibers addition [53].

The comparisons between PP and PVA fibers were carried out also using a fly ash-based geopolymer matrix [38]. The two types of PVA fiber have been used. The first of them were fibers $18 \mathrm{~mm}$ long and $0.2 \mathrm{~mm}$ in diameter, and the samples, in this case, were subjected to a high temperature of $80{ }^{\circ} \mathrm{C}$ for $8 \mathrm{~h}$ [38]. The second type of PVA fibers had dimensions: a length of $15 \mathrm{~mm}$ and a diameter of $0.3 \mathrm{~mm}$. These samples were exposed to a temperature of $85^{\circ} \mathrm{C}$ for $10 \mathrm{~h}$. The amount of fibers addition to the composites was $2.0 \%$ by volume [38]. The compressive strength for the matrix material was about $70 \mathrm{MPa}$, and for the composites with PVA fibers it was 101.9 MPa. The bending strength for the matrix material was 7.1 MPa, and for the material with 2.0\% PVA fibers 10.5 MPa [38]. Composites reinforced with PVA fibers achieved higher mechanical properties than composites with PP addition [38].

The behavior of PVA fibers was also compared with steel and glass fibers [54]. The geopolymer matrix consisted of fly ash, slag, and sand. PVA fibers were $12 \mathrm{~mm}$ long and have $15 \mu \mathrm{m}$ in diameter. The fibers were added at $1 \%$ and $2 \%$ by volume [54]. The tests were carried out after $3,7,14$, and 28 days, which allowed to observe an increase in the mechanical properties of composites over time [54]. After 28 days, the compressive strength value for the samples with $1 \%$ addition of fibers was lower than for the material without the filler and was about $41 \mathrm{MPa}$; for the material with $2 \%$ fibers, it was the same as for the geopolymer without additives-about $45 \mathrm{MPa}$. These results were lower than for composites with the addition of steel fibers and slightly higher than for composites with glass fiber [54]. The flexural strength was 4.5 MPa for 1\% PVA fibers addition and $5 \mathrm{MPa}$ for $2 \%$ PVA fiber addition, respectively. It was not referred to the flexural strength of the matrix material. The obtained values are comparable for glass fibers and some types of steel fiber reinforcement. Other types of steel fibers reinforcement gave better results—about 6.5 MPa [54]. The studies also have shown a change in the nature of the fracture from brittle to ductile in the case of the addition of fibers [54]. Similar results were obtained for the geopolymer composites prepared based on metakaolin combined with fly ash class F (from the Qingzhou power plant in Hong Kong) [55]. The fibers used for this research had a diameter of $14 \mu \mathrm{m}$ and a length of $6 \mathrm{~mm}$. The fibers were added in $1 \%$ and $2 \%$ of the volume. In the 
prepared composites, it was possible to observe a change in the crack character from brittle to ductile with the addition of fibers [55].

Research with the use of PVA fibers was also carried out on two geopolymer matrices based on fly ash, class C and class F [56]. The study used PVA fibers $15 \mathrm{~mm}$ long and $37 \mu \mathrm{m}$ in diameter in the amount of $0.5 \%, 1.0 \%$, and $1.5 \%$ by weight [56]. The research showed better results for tensile strength for composites based on class $C$ fly ash. The optimal fibers content was $1.0 \%$ by weight [56]. Research with the use of PVA fibers was also carried out with the use of a metakaolin matrix with the addition of slags from the Italian company Acciaieria di Rubiera SpA in Casalgrande [57]. The flexural properties of the composites with $1.0 \%$ by weight of PVA fibers with a diameter of $18 \mu \mathrm{m}$ and a length of $7 \mathrm{~mm}$ were tested. The flexural strength for the plain matrix was $6.9 \mathrm{MPa}$, and for composites with reinforcement it was 11.2 MPa [57]. The research was also conducted on the composites based on a metakaolin matrix with the addition of fly ash class $\mathrm{F}$ and sand $[58,59]$. The received properties were compared to traditional concrete materials [58]. The samples were prepared with a $2 \%$ addition of PVA fibers. Two kinds of fibers were used: diameter: $40 \mu \mathrm{m}$ and length $8 \mathrm{~mm}[58,59]$ and diameter: $0.1 \mathrm{~mm}$ and length $12 \mathrm{~mm}$ [57]. The research was carried out after 28 days. The results of the research showed that the composites based on the geopolymer matrix achieved lower or comparable values of the flexural strength than composites based on traditional concrete, but the geopolymer composites were characterized by a more ductile cracking mechanism [58,59]. Slightly better results were achieved with smaller fibers (smaller diameter and shorter length) [33].

The PVA fibers (diameter $0.04 \mathrm{~mm}$ and length $8 \mathrm{~mm}$ ) were also added in $2.0 \%$ by volume to a geopolymer based on fly ash class F from the Gladstone power plant in Queensland, Australia. Two types of activators based on sodium and potassium were used in this research [60,61]. The tests were carried out after 28 days. The properties of the new composites were compared with the plain matrix material as well as concrete based on Portland cement. The results show an improvement in compressive strength and very good properties of the geopolymer in terms of flexural strength $[60,61]$. The best compressive strength results were obtained for the sodium activated matrix, it was $54.6 \mathrm{MPa}$ for the matrix material and $63.7 \mathrm{MPa}$ for the composite with fibers [60,61]. Some increase in the flexural strength was also noted, but the properties for the new composites were lower than for the concrete based on Portland cement [60,61].

It is also worth paying attention to research with PVA fibers based on fly ash from the Yangluo power plant in Wuhan city, Hubei province, China, and slag from the Wuhan Iron and Steel Group plant in Wuhan city, Hubei province in China [62]. The tests were carried out with $0 \%, 0.5 \%, 1 \%, 1.5 \%$, and $2 \%$ by weight addition of two PVA fibers: length $8 \mathrm{~mm}$ and diameter $40 \mu \mathrm{m}$ and length $12 \mathrm{~mm}$ and diameter $100 \mu \mathrm{m}$ [62]. Measurements were made on samples after 3, 7, and 28 days. The results showed an increase in mechanical properties for all composites with the PVA fibers. the compressive strength for the samples with $2 \%$ content of the first type of fibers (length $8 \mathrm{~mm}$ ) was after 28 days almost $85 \mathrm{MPa}$, for comparison, the strength of the matrix material after the same time was 49.2 MPa [62]. The highest value of the flexural strength was also obtained for $2 \%$ fibers content, but it was the second type of fiber (length of $12 \mathrm{~mm}$ ). The value after 28 days was $18.2 \mathrm{MPa}$, compared to the plain matrix value of 4.8 MPa [62].

Slightly different results are shown by Borges et al. [63]. This work was carried out on composites with a metakaolin matrix reinforced by PVA fibers (length of $8 \mathrm{~mm}$, a diameter of $40 \mu \mathrm{m}$ ) in the following proportions: $1 \%$ and $2 \%$ by volume [63]. The tests were carried out on samples at 28 days after their preparation. The tests show a decrease of the compressive strength from the value of $61 \mathrm{MPa}$ for the matrix material to $59 \mathrm{MPa}$ for the composite with $1 \%$ addition of fibers and $50 \mathrm{MPa}$ for the material containing $2 \%$ of PVA fibers. The flexural strength of composites with fibers for composites with $2 \%$ fiber content increased. It was about $8 \mathrm{MPa}$. For the composite with $1 \%$ fiber content, it decreased and it was about 3.5 MPa, compared to $4 \mathrm{MPa}$ obtained for the plain matrix [63]. Similar behavior of the geopolymer composites was observed by Ekaputri et al. [64]. The compressive strength for composites with additions of $0 \%, 0.3 \%, 0.6 \%$, and $1 \%$ by weight of PVA fibers in the 
metakaolin matrix was investigated [64]. While for composites with $1 \%$ of fibers the compressive strength increased, for composites with $0.3 \%$ and $0.6 \%$ PVA fibers, the compressive strength decreased, compared to the matrix material [64]. The authors tried to link this behavior of the material with the number of voids in each composition $[63,64]$.

The necessity to select the correct proportion of fibers is also shown by $\mathrm{Xu}$ et al. [65]. The research was conducted on a matrix composed of fly ash from Hangzhou Yi-solid New Material Technology Co., Ltd. in China and sand [65]. The experiments were carried out with 3\%, 5\%, and $7 \%$ addition of PVA fibers by weight. The PVA fibers were $8 \mathrm{~mm}$ in length and have a diameter of $39 \mu \mathrm{m}$ [65]. The tests were undertaken after 7,14 , and 28 days. The mechanical properties of the prepared compositions increased over time. The results of the research showed that the optimal addition for the composite is $7 \%$ of the fiber due to the compressive strength and $5 \%$ of the fibers due to flexural strength [65]. The compressive strength after 28 days increased from $40.2 \mathrm{MPa}$ for the matrix material to $43.6 \mathrm{MPa}$ for the composite with a $7 \%$ addition of PVA fibers. The flexural strength after 28 days for the matrix material was $3.56 \mathrm{MPa}$, and for the material with $5 \%$ fiber addition it was $6.9 \mathrm{MPa}$; for the composite with $7 \%$ addition, it was slightly lower at 5.4 MPa [65].

The geopolymer composites with PVA fibers addition were also investigated by Yuan et al. [48]. The matrix was made from fly ash with different slag addition. The PVA fibers (length $12 \mathrm{~mm}$ and diameter $20 \mu \mathrm{m}$ ) were added to the mixture at $0.15 \%, 0.30 \%$, and $0.45 \%$ by volume [ 48 ]. In the case of composites with a 10\% slag amount the compressive strength slightly decreased after PVA fibers addition; from $80 \mathrm{MPa}$ for the matrix to $74.1 \mathrm{MPa}$ for $0.15 \%$ vol. PVA fibers, $79.6 \mathrm{MPa}$ for $0.30 \%$, and 0.45 vol. $\%$ for the composites with fibers [48]. For the composites with $50 \%$ of slag after $0.30 \%$ vol. PVA fibers addition the compressive strength increased from 82.0 MPa to 94.1 $\mathrm{MPa}$ [48].

Significant improvement of the flexural strength for the geopolymers reinforced by $2 \%$ PVA fibers (length: $12 \mathrm{~mm}$, a diameter of $39 \mu \mathrm{m}$ ) is shown by Wan et al. [66]. They research matrix with different slag addition and the fly ash and sand and for all investigated composition the addition of the fibers improved the flexural strength as well as initial fracture toughness and unstable fracture toughness of geopolymer [66].

Zhang et al. investigated the geopolymers based on metakaolin and fly ash. The PVA fibers (length of $12 \mathrm{~mm}$, diameter of $40 \mu \mathrm{m}$ ) were added in $0.2 \%, 0.4 \%, 0.6 \%, 0.8 \%, 1.0 \%$ and $1.2 \%$ proportions by volume [67]. The best result for compressive strength was for the composite with $0.8 \%$ fibers addition-ca. $65 \mathrm{MPa}$, comparison with plain matrix - 50 MPa. The flexural strength has the highest value for the composite with $1.2 \%$ fibers additions-10 MPa, compared to the plain matrix-6.5 $\mathrm{MPa}$ [67].

The other research shows the potential applications for geopolymer composites reinforced by PVA fibers for different kinds of engineering applications, including structures [68,69], fire resistance products for the construction industry [70], and for maintained work, including repair of concrete structures [71].

\subsection{Polyvinyl Chloride (PVC)}

Research with the use of PVC fibers was carried out based on a metakaolin matrix with the addition of slag from the Italian company Acciaieria di Rubiera SpA, in the town of Casalgrande [57]. The bending properties of composites with $1.0 \%$ by weight of PVC fibers (diameter of $400 \mu \mathrm{m}$, length of $7 \mathrm{~mm}$ ) were tested. The flexural strength for the plain matrix was $6.9 \mathrm{MPa}$, and for composites with reinforcement $10.0 \mathrm{MPa}$ [57]. These values were slightly lower than for composites with PVA fibers [57].

\subsection{Other Polymer Fibers}

Tests with polyolefin fibers (PO), with the type of fibers not specified, were also carried out based on a geopolymer matrix composed of metakaolin, slag from Bolu Cement Company in Turkey, sand, and colemanite waste (a mineral from the borate group) from the Eti Mining Company mine in Turkey [20]. The PO fibers (diameter of $63 \mu \mathrm{m}$ and length of $10 \mathrm{~mm}$ ) were added with $0.4 \%, 0.8 \%$, 
and $1.2 \%$ by volume. The studies were conducted after 3,7 , and 28 days [20]. The best results of compressive strength were after 28 days, for the sample containing $0.8 \%$ by volume addition of $\mathrm{PO}$ fibers, of about $61.6 \mathrm{MPa}$. The result was slightly better than for the plain matrix. The highest result of flexural strength was obtained for the composite containing $1.2 \%$ fiber addition of $11 \mathrm{MPa}$, compared to the matrix material of $8.8 \mathrm{MPa}$ [20]. The composites reinforced by PO fibers were compared with composites based on the same matrix with the addition of basalt fibers, PVA, and PA. Compared to other composites, they obtained the lowest mechanical values [20].

The polyolefin fibers have been tested also by Noushini et al. [44]. They added two types of fibers: 48 and $55 \mathrm{~mm}$ length with a volume fraction of $0.5 \%$ to geopolymer based on fly ash and slag. The results show a decrease in mechanical properties for both types of PO fibers. After 28 days for the reference samples, the compressive strength was $50.4 \mathrm{MPa}$, and for samples with PO fibers it was 43.8 and $43.6 \mathrm{MPa}$, respectively [44]. The tensile strength also decreased from 4.1 MPa for the matrix to 3.9 and 3.5 MPa for the composite with PO fibers [44].

A matrix based on metakaolin was used for testing the addition of PLA fibers. Research work in this area was mainly related to the use of these fibers as an additive generating pores in the material $[72,73]$.

\subsection{Use of Synthetic Fibers in Hybrid Reinforcement}

Another type of reinforcement used in composites based on geopolymers is the so-called hybrid reinforcement-containing two different types of fiber. For this type of reinforcement, fibers with different properties are most often used to obtain the synergy effect [20]. Steel fibers combined with plastic fibers are most often used in this type of reinforcement. An example of this type of reinforcement is the use of short steel and PP fibers [37,74-77].

The research was carried out on a geopolymer matrix based on fly ash and silica fume, the ingredients came from a power plant in Lampang province in Thailand. Curved steel fiber (60 mm long) and PP fiber (58 mm long) were used for the composite [37]. Two types of experiments were conducted. In the first, PP fibers were replaced with steel fibers with an increment of $0.2 \%$ until a full replacement was achieved. In the first case, an increase in compressive strength was observed with an increasing amount of steel fibers in the composite. For the composite with PP fibers, the compressive strength after 28 days was $35.44 \mathrm{MPa}$, and with subsequent additions of steel fibers, it increased: 80:20—40.5 MPa, 60:40—45.2 MPa, 40:60—51.7 MPa, 20:80—56.8 MPa and 100\% steel fibers $60.57 \mathrm{MPa}$ (for the same period, the compressive strength for the material without the addition of fibers was $40.08 \mathrm{MPa}$ ) [37]. In the second experiment, steel fibers were added to the composite with an increase of $0.2 \%$, until the total volume fraction reached $2 \%$. The amount of PP fibers was constant at $1 \%$ [37]. The compressive strength also increased with an increasing amount of steel fibers and was for the addition of $1 \%$ of steel fibers and $1 \%$ of PP fibers: $73 \mathrm{MPa}$. For the remaining composites it was, respectively: $1 \%$ PP fibers and $0 \%$ steel fibers $35.4 \mathrm{MPa}, 1 \%$ PP fibers and $0.2 \%$ steel fibers $39.4 \mathrm{MPa}, 1 \%$ PP fibers and $0.4 \%$ steel fibers $43.7 \mathrm{MPa}, 1 \%$ PP fibers and $0.6 \%$ steel fibers $56.5 \mathrm{MPa}$, and $1 \% \mathrm{PP}$ fibers and $0.8 \%$ steel fibers $68.4 \mathrm{MPa}$ [37]. The research also determined the behavior of the composites in terms of flexural strength, which was similar to the compressive strength [37].

The research with the usage of PP and steel fiber reinforcement was also made on a geopolymer matrix based on fly ash class $C$. The fibers were applied in 0.5 and $1 \%$ by volume. The fibers were used in a 4:1 ratio, including steel macro fibers (length $30 \mathrm{~mm}, 0.5 \mathrm{~mm}$ diameter) and PP microfibers (length $12 \mathrm{~mm}, 18 \mu \mathrm{m}$ diameter). The tests were carried out after 28 days at temperatures ranging from $-30{ }^{\circ} \mathrm{C}$ to $300{ }^{\circ} \mathrm{C}$ [78]. The research results showed a decrease in the mechanical properties of composites when temperature increase. The best results, both in terms of compressive strength and flexural strength, were for negative temperatures [78]. For the compressive strength, the best results were obtained for samples without reinforcement-about $45 \mathrm{MPa}$, for $0.5 \%$ fiber addition about $38 \mathrm{MPa}$, and for $1 \% 30 \mathrm{MPa}$. The flexural strength for samples with $1 \%$ addition of fibers was $9 \mathrm{MPa}$ and for samples without reinforcement and with $0.5 \%$ fibers addition it was below 7.2 MPa [78]. Recently also 
the hybrid composition included PP and glass fibers [79] and compositions with PP and PO fibers are investigated [80].

The second most popular polymeric fiber for hybrid geopolymer composite is PE incorporated with steel [81-86]. This kind of composite was widely studied by Khan et al. [81-84]. The tests were carried out with the use of two types of steel fibers-spiral and curved fibers of the same length $25 \mathrm{~mm}$ and diameters of 0.55 and $0.3 \mathrm{~mm}$, respectively. The PE fibers were $12 \mathrm{~mm}$ long and had $12 \mu \mathrm{m}$ in diameter [81]. The fibers were introduced into a geopolymer matrix composed of fly ash and slag. Fly ash class F came from Gladstone Power Station in Queensland, Australia, and BGC slag came from a cement plant in Australia [81]. Four types of samples were prepared, including two types of samples containing $1 \%$ fibers ( $80 \%$ steel fibers using both types of fibers in a $50: 50$ ratio and $20 \%$ PE fibers, $80 \%$ spiral steel fibers and 20\% PE fibers), and two types of samples containing $2 \%$ fibers ( $90 \%$ steel fibers using both types of fibers in a 50:50 ratio and 10\% PE fibers, and 80\% steel fibers using both types of fibers in a 50:50 ratio and 20\% PE fibers). The samples were tested after 28 days [81]. The results show a decrease in the compressive strength of samples with mixed fibers in comparison to samples with the same content of steel fibers. Composites with hybrid fibers obtain comparable values as a matrix of $72 \mathrm{MPa}$ [81]. The hybrid fibers significantly improved the flexural strength. The flexural strength for samples without reinforcement was $3.89 \mathrm{MPa}$, and then it increased with the addition of steel fibers, for the subsequent contents it was, respectively: $1 \%-6.1 \mathrm{MPa}, 1.5 \%-6.7 \mathrm{MPa}$ and $2 \%-9.6 \mathrm{MPa}$. For samples with $1 \%$ addition of steel fibers and PE, the following values were obtained: 6.9 MPa for composites with the addition of $80 \%$ steel fibers using both types of fibers in the 50:50 ratio and $20 \%$ PE fibers, and $4.9 \mathrm{MPa}$ for composites with the addition of $80 \%$ spiral steel fibers and $20 \% \mathrm{PE}$ fibers. The highest values were obtained for composites with $2 \%$ mixed fibers, it was: $9.8 \mathrm{MPa}$ for $90 \%$ steel fibers using both types of fibers in the 50:50 ratio and 10\% PE fibers and $11.3 \mathrm{MPa}$ for $80 \%$ steel fibers with using both types of fibers in a 50:50 ratio and 20\% PE fibers [81].

The hybrid reinforcement of steel and PE fibers was also investigated in a geopolymer matrix composed of fly ash from Hong Kong, Chinese slag, and sand. Steel fibers had $13 \mathrm{~mm}$ long and $180 \mu \mathrm{m}$ in diameter and PE fibers had $13 \mathrm{~mm}$ long and $17 \mu \mathrm{m}$ in diameter. Fibers were added to the composites in the amount of $2 \%$ by volume, changing the proportions of between steel and PE fibers $(100 \%$ steel fibers, $75: 25,50: 50,25: 75$, and 100\% PE fibers). The samples were tested after 28 days [85]. The results of the compressive tests show improvement with an increase in the steel fiber content. The values for particular samples are as follows: $100 \%$ steel fibers $-78 \mathrm{MPa}, 75: 25-77 \mathrm{MPa}, 50: 50-68.2 \mathrm{MPa}$, 25:75-63.8 MPa and 100\% PE fibers-64.8 MPa [85]. At the same time, the positive effect of the addition of PE fibers on the inhibition of the cracking mechanisms has been observed. The change of the crack character from a brittle fracture to a more ductile one was confirmed [85].

Cui et al. decided to add to hybrid reinforcement additional fibers. The reinforcement includes: $1 \%$ copper-coated micro steel fiber, $1 \%$ high-strength PE fibers in volume fraction, and $0.4 \%, 0.8 \%$, and $1.2 \%$ methylcellulose in weight fraction [86]. The geopolymer matrix was based on fly ash and slag. The steel and PE fibers had a positive influence on compressive strength. Additionally, the addition of the fibers changed the damage pattern from brittle to ductile. It effectively suppresses the development of multiple micro-cracks [86]. Moreover, the methylcellulose increased the ductility of the composite [86].

Another hybrid reinforcement, a $1 \%$ addition of PVA fibers and a 1\% addition of steel fibers, was tested on a metakaolin matrix with the addition of class $\mathrm{F}$ ashes and various sand fractions [58,59]. The results were compared to the properties of traditional cement materials, as well as to composites with one type of fiber. The studies were conducted after 28 days [58,59]. The results show that the composites based on the geopolymer matrix achieved comparable values in terms of flexural strength as composites based on traditional concrete. Additionally, these composites achieved higher values compared to composites containing only PVA fibers ( $2 \%)$ and lower than composites with the addition of fibers steel $(2 \%)[58,59]$.

Carbon fiber nanotubes (diameter 30-50 nm) and PA fibers (length $5 \mathrm{~mm}$ and diameter $12 \mu \mathrm{m}$ ) were also investigated as a hybrid reinforcement [87]. The geopolymer matrix was based on metakaolin 
activated with phosphoric acid. The fibers were added in the following percentages: $0.0 \%, 0.5 \%$, $1.0 \%, 1.5 \%, 2.0 \%, 2.5 \%$ by weight [87]. The best mechanical properties were achieved for the hybrid reinforcement-the compressive strength was approximately $115 \mathrm{MPa}$ for $1.5 \%$ of the additive (for the same amount of PA fibers it was $90 \mathrm{MPa}$, and $51.7 \mathrm{MPa}$ for the plain matrix material) [87]. The best result for flexural strength was also for $1.5 \%$ addition of hybrid fibers-about $38 \mathrm{MPa}$ (for the same amount of PA fibers the strength was about $27 \mathrm{MPa}$, and for plain matrix it was $9.9 \mathrm{MPa}$ ) [87].

The hybrid reinforcement is a very promising research area. It allows to increase compressive strength and flexural strength by using different types of reinforcement.

\section{Summarized Mechanical Properties of Composites Reinforced with Polymer Fibers}

Different fibers were used for reinforced geopolymer composites (Figure 1).

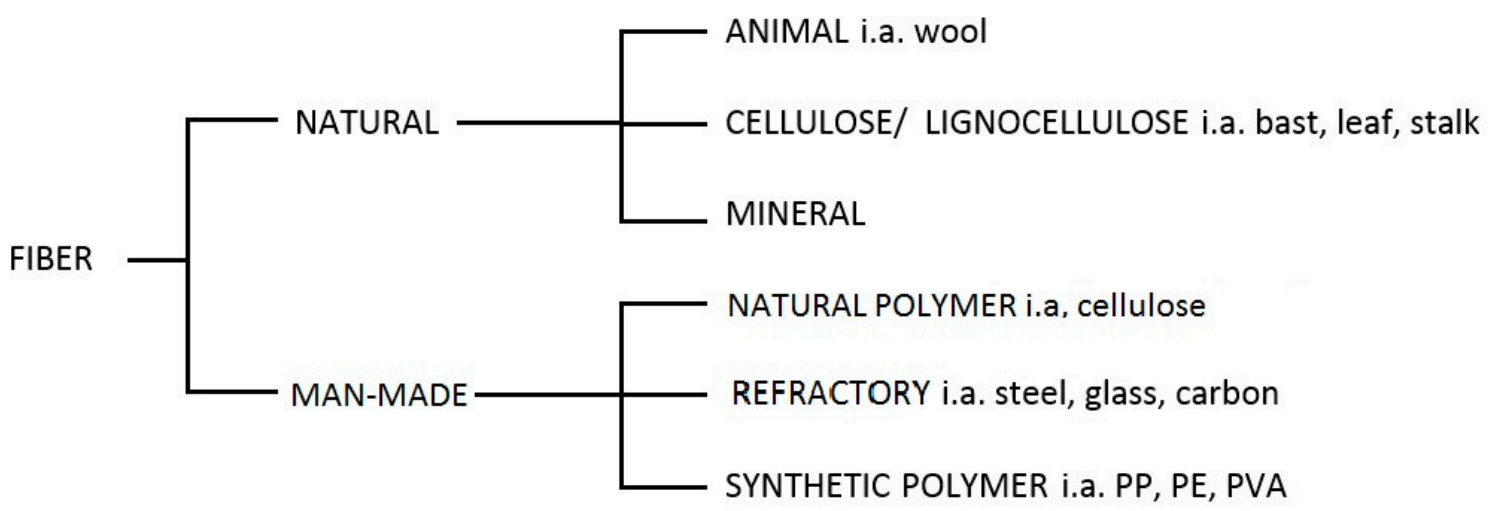

Figure 1. Overall classification of fibers used for reinforcement the geopolymer composites.

These fibers had different inherent properties such as crystallinity, thermal stability, mechanical properties etc. that could significantly influence on the final properties of the material. The basic properties such as density and tensile strength for the most popular polymer fibers are presented in Table 1.

Table 1. Basic properties of selected polymer fibers.

\begin{tabular}{ccccc}
\hline Fiber & Density $\left[\mathbf{g} / \mathbf{c m}^{\mathbf{3}}\right]$ & Tensile Strength [MPa] & Tensile Modulus [GPa] & Reference \\
\hline Aramid & $1.39-1.44$ & $3280-4120$ & $79-83$ & {$[17,88]$} \\
PAN & $1.1-1.2$ & $1000-2200$ & $35-55$ & {$[19,89]$} \\
PA & $1.09-1.37$ & $50-90$ & $0.35-20$ & {$[20,89,90]$} \\
PE & $0.96-0.98$ & $3500-4200$ & $135-235$ & {$[33,89]$} \\
PP & $0.89-0.92$ & $50-600$ & $0.5-3.0$ & {$[26-28,89]$} \\
PVA & $1.19-1.31$ & 1600 & 250 & {$[33,89]$} \\
\hline
\end{tabular}

The properties of polymer fibers can have significant influence on the composites, including the fibers pre-treatment [2]. Moreover, the fibers from different suppliers could have slightly different properties. It could cause differences in the composites properties. Nevertheless, the polymer fibers have some advantages that make their use popular, such as: more predictable properties than natural fibers, repeatable dimensions, lack of problems with cohesion into the matrix, and the possible design of the properties.

The research work carried out so far for polymer fiber-reinforced geopolymer composites shows that their addition is an effective method of improving mechanical properties. The most common applied as a reinforcement are PP and PVA fibers (Table 2.). 
Table 2. Characteristics of the short fiber-reinforced geopolymers.

\begin{tabular}{|c|c|c|c|c|}
\hline Fiber & Length & Diameter & wt. $\%$ & Reference \\
\hline Aramid & $30 \mathrm{~mm}$ & $0.5 \mathrm{~mm}$ & 1.0 vol. $\%$ & [17] \\
\hline PAN & $6 \mathrm{~mm}$ & $12 \mu \mathrm{m}$ & $0.4 \%, 0.8 \%, 1.2 \%$ & [19] \\
\hline PA & $10 \mathrm{~mm}$ & $55 \mu \mathrm{m}$ & $0.4 \%, 0.8 \%, 1.2$ vol. $\%$ & [20] \\
\hline PA & $8 \mathrm{~mm}$ & $40 \mu \mathrm{m}$ & 2.0 vol. $\%$ & [21] \\
\hline PE & $12 \mathrm{~mm}$ & $12 \mu \mathrm{m}$ & 2.0 vol. $\%$ & [21] \\
\hline PE & $12 \mathrm{~mm}$ & $12 \mu \mathrm{m}$ & $0.5 \%, 1.0 \%, 1.5 \%, 2.0 \%$ & [22] \\
\hline PP & $3 \mathrm{~mm}$ & $10 \mu \mathrm{m}$ & $0.25 \%, 0.5 \%, 0.75 \%$ & [28] \\
\hline PP & $12 \mathrm{~mm}$ & $7.5 \mu \mathrm{m}$ & $0.4 \%, 0.8 \%, 1.2$ vol. $\%$ & {$[33]$} \\
\hline PP & $12 \mathrm{~mm}$ & $18-30 \mu \mathrm{m}$ & $0.1 \%, 0.2 \%, 0.3 \%, 0.4$ vol. $\%$ & [34] \\
\hline PP & $20 \mathrm{~mm}$ & $38 \mu \mathrm{m}$ & 2.0 vol. $\%$ & [35] \\
\hline PP & $30 \mathrm{~mm}$ & $1 \mathrm{~mm}$ & 1.5 vol. $\%$ & [38] \\
\hline PP & $3-19 \mathrm{~mm}$ & $17 \mu \mathrm{m}$ & $0.5 \%, 1.0 \%, 1.5 \%, 2.0 \%$ & [39] \\
\hline PP & $6 \mathrm{~mm}$ & $11.2 \mu \mathrm{m}$ & $0.25 \%, 0.5 \%, 0.75 \%, 1.0$ vol. $\%$ & [40] \\
\hline PP & $19 \mathrm{~mm}$ & $40 \mu \mathrm{m}$ & $0.5 \%, 1.0 \%$ & [42] \\
\hline PP & $8 \mathrm{~mm}$ & $40 \mu \mathrm{m}$ & $0.1 \%, 0.2 \%, 0.3 \%, 0.4$ vol. $\%$ & [43] \\
\hline PP & 18,19 and $51 \mathrm{~mm}$ & $22 \mu \mathrm{m}$ & 0.5 vol. $\%$ & [44] \\
\hline $\mathrm{PP}$ & 10 and $15 \mathrm{~mm}$ & $50 \mu \mathrm{m}$ & $0.5 \%, 1 \%, 1.5$ vol. $\%$ & [46] \\
\hline $\mathrm{PP}$ & $6 \mathrm{~mm}$ & $20 \mu \mathrm{m}$ & $0.3 \%, 0.5 \%, 1.0 \%$ & [47] \\
\hline $\mathrm{PP}$ & $12 \mathrm{~mm}$ & $40 \mu \mathrm{m}$ & $0.15 \%, 0.30 \%, 0.45 \%$ & [48] \\
\hline PVA & $8 \mathrm{~mm}$ & $39 \mu \mathrm{m}$ & $0.4 \%, 0.8 \%, 1.2$ vol. $\%$ & [20] \\
\hline PVA & $8 \mathrm{~mm}$ & $40 \mu \mathrm{m}$ & $0.4 \%, 0.8 \%, 1.2 \%$ & [33] \\
\hline PVA & $15 / 18 \mathrm{~mm}$ & $20 / 30 \mu \mathrm{m}$ & 2.0 vol. $\%$ & [38] \\
\hline PVA & $7 \mathrm{~mm}$ & $18 \mu \mathrm{m}$ & $1.0 \%$ & [57] \\
\hline PVA & $10 \mathrm{~mm}$ & $12 \mu \mathrm{m}$ & $2.0 \mathrm{vol} . \%$ & {$[60,61]$} \\
\hline PVA & $8 / 12 \mathrm{~mm}$ & $40 / 100 \mu \mathrm{m}$ & 2.0 vol. $\%$ & [62] \\
\hline PVA & $8 \mathrm{~mm}$ & $39 \mu \mathrm{m}$ & $2.0 \%, 5.0 \%, 7.0 \%$ & [65] \\
\hline PVA & $8 \mathrm{~mm}$ & $40 \mu \mathrm{m}$ & $2.0 \%$ & [21] \\
\hline PVA & $12 \mathrm{~mm}$ & $20 \mu \mathrm{m}$ & $0.15 \%, 0.30 \%, 0.45 \%$ & [48] \\
\hline PVA & $12 \mathrm{~mm}$ & $40 \mu \mathrm{m}$ & $\begin{array}{c}0.2 \%, 0.4 \%, 0.6 \%, 0.8 \%, 1.0 \% \text {, } \\
1.2 \text { vol. } \%\end{array}$ & [67] \\
\hline PVC & $7 \mathrm{~mm}$ & $0.4 \mu \mathrm{m}$ & $1.0 \%$ & [57] \\
\hline $\mathrm{PO}$ & 48 and $55 \mathrm{~mm}$ & N/A & 0.5 vol. $\%$ & [44] \\
\hline
\end{tabular}

Most of the research work showed an improvement in both the compressive strength and the flexural strength of composites (Table 3).

Table 3. Mechanical properties for the composites-short fiber-reinforced geopolymers.

\begin{tabular}{|c|c|c|c|c|c|c|}
\hline Fiber & $\begin{array}{l}\text { Geopolymer } \\
\text { Matrix }\end{array}$ & $\begin{array}{l}\text { Compressive } \\
\text { Strength } \\
\text { (Matrix) } \\
\text { [MPa] }\end{array}$ & $\begin{array}{c}\text { Flexural } \\
\text { Strength } \\
\text { (Matrix) } \\
{[\mathrm{MPa}]}\end{array}$ & $\begin{array}{c}\text { Compressive } \\
\text { Strength } \\
\text { (Composite) } \\
\text { [MPa] }\end{array}$ & $\begin{array}{l}\text { Flexural Strength } \\
\text { (Composite) } \\
\text { [MPa] }\end{array}$ & Reference \\
\hline Aramid & Fly ash & 70.0 & 7.1 & $\begin{array}{c}88.0 \\
(+25.7 \%)\end{array}$ & $\begin{array}{c}10.4 \\
(+46.5 \%)\end{array}$ & [17] \\
\hline $\begin{array}{l}\text { PAN } \\
(0.8 \%)\end{array}$ & Metakaolin + slag & 80.0 & 4.0 & $\begin{array}{c}99.8 \\
(+24.8 \%)\end{array}$ & $\begin{array}{c}13.8 \\
(+244 \%)\end{array}$ & [19] \\
\hline $\mathrm{PA}^{1}$ & $\begin{array}{c}\text { Metakaolin + slag } \\
+ \text { sand + } \\
\text { collemanite }\end{array}$ & 61.6 & 8.8 & $\begin{array}{c}62.0 \\
(+0.6 \%)\end{array}$ & $\begin{array}{c}11.4 \\
(+22.8 \%)\end{array}$ & [20] \\
\hline PA (2.0 vol.\%) & Fly ash + slag & 48.6 & N/A & $\begin{array}{c}48.7 \\
(+0.2 \%)\end{array}$ & N/A & [21] \\
\hline PE (2.0 vol.\%) & Fly ash + slag & 48.6 & N/A & $\begin{array}{c}44.3 \\
(-8.8 \%)\end{array}$ & N/A & [21] \\
\hline PE $(0.5 \%)$ & Fly ash + slag & 80.0 & N/A & $\begin{array}{c}70.7 \\
(-11.6 \%)\end{array}$ & N/A & [22] \\
\hline $\begin{array}{c}\text { PP } \\
(0.75 \%)\end{array}$ & Metakaolin & 32.6 & 5.0 & $\begin{array}{c}54.7 \\
(+59.6 \%)\end{array}$ & $\begin{array}{c}10.0 \\
(+50 \%)\end{array}$ & [28] \\
\hline
\end{tabular}


Table 3. Cont.

\begin{tabular}{|c|c|c|c|c|c|c|}
\hline Fiber & $\begin{array}{l}\text { Geopolymer } \\
\text { Matrix }\end{array}$ & $\begin{array}{l}\text { Compressive } \\
\text { Strength } \\
\text { (Matrix) } \\
\text { [MPa] }\end{array}$ & $\begin{array}{c}\text { Flexural } \\
\text { Strength } \\
\text { (Matrix) } \\
{[\mathrm{MPa}]}\end{array}$ & $\begin{array}{l}\text { Compressive } \\
\text { Strength } \\
\text { (Composite) } \\
\text { [MPa] }\end{array}$ & $\begin{array}{c}\text { Flexural Strength } \\
\text { (Composite) } \\
{[\mathrm{MPa}]}\end{array}$ & Reference \\
\hline $\mathrm{PP}^{2}$ & $\begin{array}{c}\text { Fly ash + slag + } \\
\text { sand }\end{array}$ & 60.5 & 8.4 & $\begin{array}{c}61.0 \\
(+0.8 \%)\end{array}$ & $\begin{array}{c}9.7 \\
(+14.7 \%)\end{array}$ & [33] \\
\hline PP (0.2 vol.\%) & $\begin{array}{c}\text { Fly ash }+ \text { slag }+ \\
\text { sand }\end{array}$ & 35.0 & 6.5 & $\begin{array}{c}39.0 \\
(+10.3 \%)\end{array}$ & $\begin{array}{c}7.0 \\
(+7.4 \%)\end{array}$ & [34] \\
\hline PP (2.0 vol.\%) & Slag + sand & 80.0 & 8.0 & $\begin{array}{c}100.0 \\
(+20 \%)\end{array}$ & $32.0(+400 \%)$ & [35] \\
\hline PP (1.5 vol.\%) & Fly ash & 70.0 & 7.1 & $\begin{array}{c}91.7 \\
(+31 \%)\end{array}$ & $\begin{array}{c}8.4 \\
(+18.6 \%)\end{array}$ & [38] \\
\hline $\mathrm{PP}(0.5 \%)$ & $\begin{array}{c}\text { Fly ash (foamed } \\
\text { GP) }\end{array}$ & 0.88 & N/A & $\begin{array}{c}1.5 \\
(+70.5 \%)\end{array}$ & N/A & [39] \\
\hline $\begin{array}{c}\text { PP } \\
(0.25 \text { vol. } \%)\end{array}$ & $\begin{array}{c}\text { Fly ash }+ \\
\text { micron-scale silica }\end{array}$ & 22.3 & 7.6 & $\begin{array}{c}35.8 \\
(+60.5 \%)\end{array}$ & $\begin{array}{c}7.8 \\
(+2.6 \%)\end{array}$ & [40] \\
\hline PP $(1.0 \%)$ & Fly ash/slag & N/A & 8.8 & N/A & $\begin{array}{c}6.0 \\
(-46.7 \%)\end{array}$ & [42] \\
\hline $\mathrm{PP}(0.2 \%)$ & Metakaolin & 48.0 & 5.6 & $\begin{array}{c}49 \\
(+2.1 \%)\end{array}$ & $\begin{array}{c}6.9 \\
(+23.2 \%)\end{array}$ & [43] \\
\hline PP (0.5 vol. \%) & Fly ash + slag & 50.4 & N/A & $\begin{array}{c}47.3 \\
(-6.1 \%)\end{array}$ & N/A & {$[44]$} \\
\hline $\mathrm{PP}^{3}$ & $\begin{array}{c}\text { Fly ash + } \\
\text { aggregates }\end{array}$ & 32.0 & 5.9 & $\begin{array}{c}43.3 \\
(+35.3 \%)\end{array}$ & $\begin{array}{c}8.0 \\
(+35.5 \%)\end{array}$ & [46] \\
\hline PP $(1.0 \%)$ & $\begin{array}{l}\text { Metakaolin + } \\
\text { aggregates }\end{array}$ & 52.6 & 3.6 & $\begin{array}{c}52.7 \\
(+1.0 \%)\end{array}$ & $\begin{array}{c}4.9 \\
(+36.1 \%)\end{array}$ & [47] \\
\hline PP (0.15 vol. \%) & Fly ash + slag & 80.0 & N/A & $\begin{array}{c}74.8 \\
(-6.5 \%)\end{array}$ & N/A & [48] \\
\hline $\mathrm{PVA}^{4}$ & $\begin{array}{c}\text { Metakaolin + slag } \\
+ \text { sand + } \\
\text { collemanite }\end{array}$ & 61.6 & 8.8 & $\begin{array}{c}66.2 \\
(+7.5 \%)\end{array}$ & $12.2(+38.6 \%)$ & [20] \\
\hline $\begin{array}{c}\text { PVA } \\
\text { (1.2 vol. } \%)\end{array}$ & $\begin{array}{c}\text { Fly ash + slag + } \\
\text { sand }\end{array}$ & 60.5 & 8.4 & $\begin{array}{c}63.0 \\
(+4.3 \%)\end{array}$ & $11.8(+39.8 \%)$ & [33] \\
\hline $\begin{array}{c}\text { PVA } \\
\text { (2.0 vol. } \%)\end{array}$ & Fly ash & 70.0 & 7.1 & $\begin{array}{c}101.9 \\
(+45.6 \%)\end{array}$ & $10.5(+47.9 \%)$ & [38] \\
\hline PVA $(1.0 \%)$ & Metakaolin + slag & N/A & 6.9 & N/A & $11.2(+62.3 \%)$ & [57] \\
\hline PVA (2.0 vol.\%) & Fly ash & 54.6 & N/A & $\begin{array}{c}63.7 \\
(+16.7)\end{array}$ & N/A & {$[60,61]$} \\
\hline PVA (2.0 vol.\%) & Fly ash & 49.2 & 4.8 & $\begin{array}{c}84.9 \\
(+72.7)\end{array}$ & $18.2(+278.2 \%)$ & [62] \\
\hline $\begin{array}{l}\text { PVA } \\
(5.0 \%)\end{array}$ & Fly ash + sand & 40.2 & 3.6 & $\begin{array}{c}43.6 \\
(+8.5 \%)\end{array}$ & $\begin{array}{c}6.9 \\
(+94.1 \%)\end{array}$ & [65] \\
\hline PVA $(2.0 \%)$ & Fly ash + slag & 48.6 & N/A & $\begin{array}{c}48.7 \\
(+0.2 \%)\end{array}$ & N/A & [21] \\
\hline PVA (0.30 vol.\%) & Fly ash + slag & 82.0 & N/A & $\begin{array}{c}94.1 \\
(+12.8 \%)\end{array}$ & N/A & [48] \\
\hline PVA $^{5}$ & $\begin{array}{l}\text { Metakaolin + fly } \\
\text { ash }\end{array}$ & 50.0 & 6.5 & $\begin{array}{c}65.0 \\
(+30.0 \%)\end{array}$ & $10.0(+53.8 \%)$ & [67] \\
\hline PVC (1.0\%) & Metakaolin + slag & N/A & 6.9 & N/A & $10.0(+44.9 \%)$ & [57] \\
\hline PO (0.5 vol.\%) & Fly ash + slag & 50.4 & N/A & $\begin{array}{c}43.8 \\
(-13.1 \%)\end{array}$ & N/A & {$[44]$} \\
\hline
\end{tabular}

\footnotetext{
${ }^{1}$ Results for: compressive strength (cs) - 0.8 vol. \% of fiber and flexural strength (fs) - 1.2 vol. $\%$ of fiber. ${ }^{2}$ Results for: $\mathrm{cs}-0.4$ vol. $\%$ of fiber and fs- 1.2 vol. $\%$ of fiber. ${ }^{3}$ Results for: $\mathrm{cs}-0.5$ vol. $\%$ of fiber and fs- 1.5 vol. $\%$ of fiber (10 mm length). ${ }^{4}$ Results for: cs- 1.5 vol. $\%$ of fiber and fs- 1.2 vol. $\%$ of fiber. ${ }^{5}$ Results for: cs- 0.8 vol. $\%$ of fiber and fs- 1.2 vol. $\%$ of fiber.
}

It is worth noting that in some cases the authors report a very high flexural strength value after adding fibers, compared to the compressive strength $[19,33,62]$. These works require verification of the research methodology before the wider application of the results, as this behavior is not typical for this type of material.

The compressive strength for polymeric fibers usually increased, and only for some cases does it decrease. However, the main reason of polymer fiber addition is not a compressive strength, but the flexural strength and fracture tongues behavior. The flexural strength for presented research increased generally (about 50\%). In the case of research where it decreased or does not significantly change, the authors explained it by voids in material, fibers agglomerations or improper interfacial mechanism between fibers and matrix $[2,12,48,91,92]$. 
The most of mentioned research was focused on compressive and flexural strength of fiber-reinforced geopolymer, because of planned applications in the construction industry. Some investigations also discussed other mechanical properties such as tensile strength $[17,21,25,33,91]$. The research shows the increasing tensile strength is correlated with increasing of flexural strength. The improving the tensile performance of the composites is also important factor for fibers addition [92].

Another important reason for fiber reinforcement is fracture toughness, including changing the fracture form brittle to more ductile [2]. These mechanism were observed by some authors $[21-24,54-59,85,86]$. It was mainly described together with results of flexural strength as a changes in material behavior. The polymer fibers have significant influence on that mechanism by the energy absorption and limitation of micro-cracks propagation [2,12]. Fracture toughness is important for polymer fiber composites, because it expand the area of application for this materials. The more ductile mechanism increased safety of buildings in such situations as fire or earthquakes, because it gives time for evacuation.

\section{Comparison of the Properties of Composites with Traditional Building Materials}

The values of the obtained mechanical properties can be compared to traditional building materials. The value obtained for the geopolymer matrix can be compared to the properties of the most popular concretes, which are used practically at every stage of building a house, both from pouring foundation alloys, foundation slabs or the foundations themselves, as well as for various types of foundation, walls, columns, lintels, terraces, stairs, ceilings, etc. It is used both in internal and external applications, including for pouring and embedding fence posts and for making small concrete elements and small architecture. The values given for this type of concretes are usually: the compressive strength of $20 \mathrm{MPa}$ and the flexural strength above $4 \mathrm{MPa}$. In all these applications, the said concrete can be replaced by a geopolymer material.

Moreover, the addition of fibers increased the mechanical properties of composites and made it possible to meet the requirements for the so-called architectural concretes, i.e., the compressive strength of $35 \mathrm{MPa}$ and the flexural strength of $8 \mathrm{MPa}$, which allows their use for complex spatial elements. Selected composites allow for specialized applications-Table 4 . The addition of fibers not only increased the mechanical properties but also improved other properties of composites, such as resistance to high temperatures and durability $[8,41,91]$.

Table 4. Area of investigated applications for the composites-short fibers reinforced geopolymers.

\begin{tabular}{ccc}
\hline Area of Application & Fiber & Reference \\
\hline High-temperature resistant & PA, PP, PVA & {$[9,20,39,52,70]$} \\
Structures & PAN, PP, PVA & {$[19,27,68,69]$} \\
Lightweight application & PP & {$[39,50,51]$} \\
Repair works & PVA & {$[71]$} \\
Isolation material & PP & {$[39,49-51]$} \\
3D printing technology & PP, PVA, PBO & {$[40,41]$} \\
\hline
\end{tabular}

\section{Contemporary Research Challenges for Geopolymer Materials Reinforced with Fibers}

The area of research on geopolymers reinforced with fibers, in particular short fibers, faces many challenges $[12,91,92]$. Some of them are related to the geopolymer material itself, others to the proper functioning of the fiber-matrix system. Eventually, the specific research issues connected with fiber-reinforcement for geopolymer composites are required. The many types of fibers have not been tested in terms of their applicability in such composites yet [41,93]. It is also necessary to conduct more comprehensive and advanced research in this area since in the case of many fibers only preliminary tests were performed on a small number of samples, which were not followed up further $[1,8,91,94]$.

One of the most important research challenges related to the properties of the geopolymer matrix is the variable quality and composition of fly ash. This causes not only the problem of comparing research 
results between particular works but above all problems with the implementation of geopolymers based on recyclable materials in practice $[1,94,95]$. One of the possible solutions to this problem is geopolymers based on metakaolin. However, important environmental benefits are then lost, in the form of the possibility of managing anthropogenic waste $[95,96]$. When treating the problem a bit more broadly, it is worth noting that there is also the possibility of developing geopolymer materials based on other types of waste. Research in this area was carried out, among others with the use of waste from coal mining, in particular, the so-called gangues and also wastes from the extraction of metal ores [96].

Another research challenge related to the geopolymer material itself is the small amount of data on the durability of the material and the lack of appropriate standards defining the possibilities of its applications $[12,51,70,97]$. It should be noted that the durability of traditional building materials is also questioned by many scientific works [98]. Theoretical predictions show the long-term usefulness of geopolymer materials [98], however, no studies confirm these calculations in practice. Preparation and carrying out of such tests for individual materials is necessary for their implementation in practice.

The next research challenge is also the optimization of the production process of these materials. In this aspect, it is worth mentioning the elimination of the curing at high temperatures and the possibility of developing geopolymer materials hardened at ambient temperature $[23,29,79,81,83-85]$. Such research works are undertaken in some research centers, but they do not always allow obtaining materials with satisfactory mechanical properties $[29,44]$. Such work is currently carried out for composites with polymer fibers and brings much better results than for a plain matrix $[79,81,83-85]$. The second solution that allows the price of materials to be reduced, and at the same time the safety of their production to be improved, is to replace the alkaline compounds used in the geopolymerization process with acids. Currently, work in this field is carried out in several centers around the world, with the best results being obtained in China [87,99].

Currently, an important direction of development is the creation of new materials friendly for the environment. There is a significant market demand for ecological materials, and in particular for materials based on renewable raw materials or waste products. The rational management of natural resources and the use of waste materials are becoming increasingly important. It also gives the chance to use polymer waste fibers $[95,100]$. The growing ecological awareness of society, including the awareness of sustainable development, means that the issue of environmental impact is increasingly being discussed. Modern composites, based on geopolymers, allow to reduce the emission of substances harmful for the environment and at the same time save natural resources by waste using [2,100]. Geopolymer composites, in particular with fiber reinforcements, intended for advanced applications, are part of the sustainable development policy that is currently a guideline for the creation of legal standards in many countries in Europe and the world [1].

\section{Conclusions}

Research on the possibility of creating new geopolymer composites with additives of various types of short polymer fibers is constantly being developed across the world. This problem is still insufficiently researched. The available literature does not describe research with the use of many possible fillers, such as melamine fibers, and therefore it is possible to conduct both experimental work and theoretical considerations creating models of behavior of given composites. This research area offers a lot of opportunities for future scientific exploration of the topic as well as new possibilities for the practical application of these kinds of material.

Author Contributions: Conceptualization, K.K.; methodology, K.K.; validation, W.-T.L., and H.Š.; formal analysis, W.-T.L., and K.K.; investigation, K.K.; writing-original draft preparation, K.K.; writing-review and editing, W.-T.L. and H.Š.; supervision, K.K. and H.Š.; funding acquisition, K.K. and H.Š. All authors have read and agreed to the published version of the manuscript.

Funding: This work has been financed by Polish National Agency for Academic Exchange under the International Academic Partnership Programme within the framework of the grant: 'E-mobility and sustainable materials and technologies EMMAT' (PPI/APM/2018/1/00027) and in the framework of bilateral exchange of researchers 
between Poland and the Czech Republic the grant: 'Fibers Reinforced Geopolymers' (Polish designation PPN/BCZ/2019/1/00005/U/00001, the Czech designation 8J20PL073).

Conflicts of Interest: The authors declare no conflict of interest.

\section{References}

1. Silva, G.; Kim, S.; Aguilar, R.; Nakamatsu, J. Natural fibers as reinforcement additives for geopolymers-A review of potential eco-friendly applications to the construction industry. Sustain. Mat. Technol. 2020, 23, e00132. [CrossRef]

2. Korniejenko, K.; Łach, M.; Dogan-Saglamtimur, N.; Furtos, G.; Mikuła, J. The overview of mechanical properties of short natural fiber reinforced geopolymer composites. Environ. Res. Technol. 2020, 3, $28-39$. [CrossRef]

3. Chen, R.; Ahmari, S.; Zhang, L. Utilization of sweet sorghum fiber to reinforce fly ash-based geopolymer. J. Mater. Sci. 2014, 49, 2548-2558. [CrossRef]

4. Ma, C.K.; Awang, A.Z.; Omar, W. Structural and material performance of geopolymer concrete: A review. Constr. Build. Mater. 2018, 186, 90-102. [CrossRef]

5. Sitarz, M.; Hager, I.; Choińska, M. Evolution of mechanical properties with time of fly-ash-based geopolymer mortars under the effect of granulated ground blast furnace slag addition. Energies 2020, 13, 1135. [CrossRef]

6. Sitarz, M.; Hager, I.; Kochanek, J. Effect of high temperature on mechanical properties of geopolymer mortar. MATEC Web Conf. 2018, 163, 06004. [CrossRef]

7. Mierzwiński, D.; Łach, M.; Hebda, M.; Walter, J.; Szechyńska-Hebda, M.; Mikuła, J. Thermal phenomena of alkali-activated metakaolin studied with a negative temperature coefficient system. J. Therm. Anal. Calorim. 2019, 138, 4167-4175. [CrossRef]

8. Ranjbar, N.; Zhang, M. Fiber-Reinforced geopolymer composites: A review. Cem. Concr. Compos. 2020, 107, 103498. [CrossRef]

9. Rickard, W.D.A.; Vickers, L.; van Riessen, A. Performance of fibre reinforced, low density metakaolin geopolymers under simulated fire conditions. Appl. Clay Sci. 2013, 73, 71-77. [CrossRef]

10. Silva, G.; Kim, S.; Bertolotti, B.; Nakamatsu, J.; Aguilar, R. Optimization of a reinforced geopolymer composite using natural fibers and construction wastes. Constr. Build. Mater. 2020, 258, 119697. [CrossRef]

11. Lin, T.; Jia, D.; Wang, M.; He, P.; Liang, D. Effects of fibre content on mechanical properties and fracture behaviour of short carbon fibre reinforced geopolymer matrix composites. Bull. Mater. Sci. 2009, 32, 77-81. [CrossRef]

12. Sakulich, A.R. Reinforced geopolymer composites for enhanced material greenness and durability. Sustain. Cities Soc. 2011, 1, 195-210. [CrossRef]

13. Korniejenko, K.; Łach, M.; Doğan-Sağlamtimur, N.; Furtos, G.; Mikuła, J. Fibre reinforced geopolymer composites-A review. In Proceedings of the 1st International Conference on Environment, Technology and Management (ICETEM), Niğde, Turkey, 27-29 June 2019; Kacar, İ., Ed.; Niğde Ömer Halisdemir University: Niğde, Turkey, 2019; pp. 3-13.

14. Silva, F.J.; Thaumaturgo, C. Fibre reinforcement and fracture response in geopolymeric mortars. Fatigue Fract. Eng. Mater. Struct. 2003, 26, 167-172. [CrossRef]

15. Gailitis, R.; Sliseris, J.; Korniejenko, K.; Mikuła, J.; Łach, M.; Pakrastins, L.; Sprince, A. Long-Term deformation properties of a carbon fiber-reinforced alkali-activated cement composite. Mech. Compos. Mat. 2020, 56, 85-92. [CrossRef]

16. Kuciel, S.; Jakubowska, P.; Kuźniar, P. A study on the mechanical properties and the influence of water uptake and temperature on biocomposites based on polyethylene from renewable sources. Compos. Part B Eng. 2014, 64, 72-77. [CrossRef]

17. Łach, M.; Hebdowska-Krupa, M.; Mierzwiński, D.; Korniejenko, K. Mechanical properties of geopolymers reinforced with carbon and aramid long fibers. IOP Conf. Ser. Mater. Sci. Eng. 2019, 706, 012011. [CrossRef]

18. Korniejenko, K.; Łach, M.; Chou, S.-Y.; Lin, W.-T.; Mikuła, J.; Mierzwiński, D.; Cheng, A.; Hebda, M. A comparative study of mechanical properties of fly ash-based geopolymer made by casted and 3D Printing methods. IOP Conf. Ser. Mater. Sci. Eng. 2019, 660, 012005. [CrossRef]

19. Luo, C.; Wang, A.C. Effects of short pan fiber contents on mechanical properties of metakaolin-blast furnace slag based geopolymers. Key Eng. Mat. 2015, 697, 608-611. [CrossRef] 
20. Celik, A.; Yilmaz, K.; Canpolat, O.; Al-Mashhadani, M.M.; Aygörmez, Y.; Uysal, M. High-Temperature behavior and mechanical characteristics of boron waste additive metakaolin based geopolymer composites reinforced with synthetic fibers. Constr. Build. Mater. 2018, 187, 1190-1203. [CrossRef]

21. Nematollahi, B.; Sanjayan, J.; Qiu, J.; Yang, E.H. High ductile behavior of a polyethylene fiber-reinforced one-part geopolymer composite: A micromechanics-based investigation. Arch. Civ. Mech. Eng. 2017, 17, 555-563. [CrossRef]

22. Ahmed, S.F.U.; Ronnie, Z. Ductile behavior of polyethylene fibre reinforced geopolymer composite. MATEC Web Conf. 2017, 97, 01047. [CrossRef]

23. Shaikh, F.U.A.; Fairchild, A. Strain hardening behaviour of polyethylene fibre reinforced ambient air cured geopolymer composite. In Strain-Hardening Cement-Based Composites; Mechtcherine, V., Slowik, V., Kabele, P., Eds.; SHCC 2017, RILEM Bookseries; Springer: Dordrecht, The Netherlands; Berlin/Heidelberg, Germany, 2017; Volume 15, pp. $162-170$.

24. Choi, J.I.; Lee, B.Y.; Ranade, R.; Li, V.C.; Lee, Y. Ultra-High-Ductile behavior of a polyethylene fiber-reinforced alkali activated slag-based composite. Cem. Concr. Compos. 2016, 70, 153-158. [CrossRef]

25. Shaikh, F.U.A. Tensile and flexural behaviour of recycled polyethylene terephthalate (PET) fibre reinforced geopolymer composites. Constr. Build. Mater. 2020, 245, 118438. [CrossRef]

26. Puertas, F.; Amat, T.; Fernandez-Jimenez, A.; Vazquez, T. Mechanical and durable behaviour of alkaline cement mortars reinforced with polypropylene fibres. Cem. Concr. Res. 2003, 33, 2031-2036. [CrossRef]

27. Puertas, F.; Amat, T.; Vázquez, T. Behaviour of alkaline cement mortars reinforced with acrylic and polypropylene fibres. Mater. Constr. 2000, 259, 69-84. [CrossRef]

28. Zhang, Z.; Yao, X.; Zhu, H.; Hua, S.; Chen, Y. Preparation and mechanical properties of polypropylene fiber reinforced calcined kaolin-fly ash based geopolymer. J. Cent. South Univ. Technol. 2009, 16, 49-52. [CrossRef]

29. Reed, M.; Lokuge, W.; Karunasena, W. Fibre-Reinforced geopolymer concrete with ambient curing for in situ applications. J. Mat. Sci. 2014, 49, 4297-4304. [CrossRef]

30. Korniejenko, K.; Mikuła, J.; Łach, M. Fly ash based fiber-reinforced geopolymer composites as the environmental friendly alternative to cementitious materials. In Proceedings of the 2015 International Conference on Bio-Medical Engineering and Environmental Technology (BMEET-15), London, UK, 21-22 March 2015; pp. 208-214.

31. Ranjbar, N.; Mehrali, M.; Behnia, A.; Pordsari, A.J.; Mehrali, M.; Alengaram, U.J.; Jumaat, M.Z. A comprehensive study of the polypropylene fiber reinforced fly ash based geopolymer. PLoS ONE 2016, 11, 0147546-0147566. [CrossRef]

32. Ranjbar, N.; Talebian, S.; Mehrali, M.; Kuenzel, C.; Metselaar, H.S.C.; Jumaat, M.Z. Mechanisms of interfacial bond in steel and polypropylene fiber reinforced geopolymer composites. Compos. Sci. Technol. 2016, 122, 73-81. [CrossRef]

33. Al-Mashhadani, M.M.; Canpolat, O.; Aygörmez, Y.; Uysal, M.; Erdem, S. Mechanical and microstructural characterization of fiber reinforced fly ash based geopolymer composites. Constr. Build. Mater. 2018, 167, 505-513. [CrossRef]

34. Guo, X.; Pant, X. Mechanical properties and mechanisms of fiber reinforced fly ash-steel slag based geopolymer mortar. Constr. Build. Mater. 2018, 179, 633-641. [CrossRef]

35. Nguyen, H.; Carvelli, V.; Adesanya, E.; Kinnunen, P.; Illikainen, M. High performance cementitious composite from alkali-activated ladle slag reinforced with polypropylene fibers. Cem. Concr. Compos. 2018, 90, 150-160. [CrossRef]

36. Chindaprasirt, P.; Rattanasak, U. Synthesis of polypropylene fiber/high-calcium fly ash geopolymer with outdoor heat exposure. Clean Technol. Environ. 2017, 19, 1985-1992. [CrossRef]

37. Sukontasukkul, P.; Pongsopha, P.; Chindaprasirt, P.; Songpiriyakij, S. Flexural performance and toughness of hybrid steel and polypropylene fibre reinforced geopolymer. Constr. Build. Mater. 2018, 161, 37-44. [CrossRef]

38. Zhu, J.; Zheng, W.Z.; Qin, C.Z.; Xu, Z.Z.; Wu, Y.Q. Effect of different fibers on mechanical properties and ductility of alkali-activated slag cementitious material. IOP Conf. Ser. Mater. Sci. Eng. 2018, 292, 012060. [CrossRef]

39. Wang, Y.; Zheng, T.; Zheng, X.; Liu, Y.; Darkwa, J.; Zhou, G. Thermo-mechanical and moisture absorption properties of fly ash-based lightweight geopolymer concrete reinforced by polypropylene fibers. Constr. Build. Mater. 2020, 251, 118960. [CrossRef] 
40. Nematollahi, B.; Vijay, P.; Sanjayan, J.; Nazari, A.; Xia, M.; Nerella, V.N.; Mechtcherine, V. Effect of polypropylene fibre addition on properties of geopolymers made by $3 \mathrm{D}$ printing for digital construction. Materials 2018, 11, 2352. [CrossRef] [PubMed]

41. Korniejenko, K.; Łach, M. Geopolymers reinforced by short and long fibres-Innovative materials for additive manufacturing. Curr. Opin. Chem. Eng. 2020, 28, 167-172. [CrossRef]

42. Bagheri, A.; Nazari, A.; Sanjayan, J.G. Fibre-Reinforced boroaluminosilicate geopolymers: A comparative study. Ceram. Int. 2018, 44, 16599-16605. [CrossRef]

43. Chen, X.; Zhou, Z.; Shen, W.; Zhu, G.; Ge, X. Mechanical properties and microstructure of metakaolin-based geopolymer compound-modified by polyacrylic emulsion and polypropylene fibers. Constr. Build. Mater. 2018, 190, 680-690. [CrossRef]

44. Noushini, A.; Castel, A.; Gilbert, R.I. Creep and shrinkage of synthetic fibre-reinforced geopolymer concrete. Mag. Concr. Res. 2019, 71, 1070-1082. [CrossRef]

45. Baykara, H.; Cornejo, M.H.; Espinoza, A.; García, E.; Ulloa, N. Preparation, characterization, and evaluation of compressive strength of polypropylene fiber reinforced geopolymer mortars. Heliyon 2020, 6, e03755. [CrossRef] [PubMed]

46. Pham, K.V.A.; Nguyen, T.K.; Le, T.A.; Han, S.W.; Lee, G.; Lee, K. Assessment of performance of fiber reinforced geopolymer composites by experiment and simulation analysis. Appl. Sci. 2019, 9, 3424. [CrossRef]

47. Behforouz, B.; Balkanlou, V.S.; Naseri, F.; Kasehchi, E.; Mohseni, E.; Ozbakkaloglu, T. Investigation of eco-friendly fiber-reinforced geopolymer composites incorporating recycled coarse aggregates. Int. J. Environ. Sci. Technol. 2020, 17, 3251-3260. [CrossRef]

48. Yuan, Y.; Zhao, R.; Li, R.; Wang, Y.; Cheng, Z.; Li, F.; Ma, Z.J. Frost resistance of fiber-reinforced blended slag and Class F fly ash-based geopolymer concrete under the coupling effect of freeze-thaw cycling and axial compressive loading. Constr. Build. Mater. 2020, 250, 118831. [CrossRef]

49. Su, Z.; Guo, L.; Zhang, Z.; Duan, P. Influence of different fibers on properties of thermal insulation composites based on geopolymer blended with glazed hollow bead. Constr. Build. Mater. 2019, 203, 525-540. [CrossRef]

50. Utami, F.A.R.; Triwiyono, A.; Agustini, N.K.A.; Perdana, I. Thermal conductivity of geopolymer with polypropylene fiber. IOP Conf. Ser. Mater. Sci. Eng. 2020, 742, 012031. [CrossRef]

51. Mohseni, E.; Kazemi, M.J.; Koushkbaghi, M.; Zehtab, B.; Behforouz, B. Evaluation of mechanical and durability properties of fiber-reinforced lightweight geopolymer composites based on rice husk ash and nanoalumina. Constr. Build. Mater. 2019, 209, 532-540. [CrossRef]

52. Aygörmez, Y.; Canpolat, O.; Al-Mashhadani, M.M.; Uysal, M. Elevated temperature, freezing-thawing and wetting-drying effects on polypropylene fiber reinforced metakaolin based geopolymer composites. Constr. Build. Mater. 2020, 235, 117502. [CrossRef]

53. Masi, G.; Rickard, W.D.A.; Bignozzi, M.C.; van Riessen, A. The effect of organic and inorganic fibres on the mechanical and thermal properties of aluminate activated geopolymers. Compos. Part B 2015, 76, 218-228. [CrossRef]

54. Al-Majidi, M.H.; Lampropoulos, A.; Cundy, A.B. Tensile properties of a novel fibre reinforced geopolymer composite with enhanced strain hardening characteristics. Compos. Struct. 2017, 168, 402-427. [CrossRef]

55. Zhang, Y.; Sun, W.; Li, Z. Impact behavior and microstructural characteristics of PVA fiber reinforced fly ash-geopolymer boards prepared by extrusion technique. J. Mater. Sci. 2006, 41, 2787-2794.

56. Peijiang, S.; Hwai-Chung, W. Transition from brittle to ductile behavior of fly ash using PVA fibers. Cem. Concr. Compos. 2008, 30, 29-36.

57. Natali, A.; Manzi, S.; Bignozzi, M.C. Novel fiber-reinforced composite materials based on sustainable geopolymer matrix. Procedia Eng. 2011, 21, 1124-1131. [CrossRef]

58. Shaikh, F.U.A. Deflection hardening behaviour of short fibre reinforced fly ash based geopolymer composites. Mater. Des. 2013, 50, 674-682. [CrossRef]

59. Shaikh, F.U.A. Review of mechanical properties of short fibre reinforced geopolymer composities. Constr. Build. Mater. 2013, 43, 37-49. [CrossRef]

60. Nematollahi, B.; Sanjayan, J.; Shaikh, F.U.A. Comparative deflection hardening behavior of short fiber reinforced geopolymer composites. Constr. Build. Mater. 2014, 70, 54-64. [CrossRef]

61. Nematollahi, B.; Sanjayan, J.; Shaikh, F.U.A. Tensile strain hardening behavior of PVA fiber-reinforced engineered geopolymer composite. J. Mater. Civ. Eng. 2014, 27, 04015001. [CrossRef] 
62. Xu, F.; Deng, X.; Peng, C.; Zhu, J.; Chen, J. Mix design and flexural toughness of PVA fiber reinforced fly ash-geopolymer composites. Constr. Build. Mater. 2017, 150, 179-189. [CrossRef]

63. Borges, P.H.R.; Bhutta, A.; Bavuzo, L.T.; Banthia, N. Effect of SiO2/Al2O3 molar ratio on mechanical behavior and capillary sorption of MK-based alkali-activated composites reinforced with PVA fibers. Mater. Struct. 2017, 50, 148-160. [CrossRef]

64. Ekaputri, J.J.; Junaedi, S. Effect of curing temperature and fiber on metakaolin-based geopolymers. Procedia Eng. 2017, 171, 572-583. [CrossRef]

65. Xu, S.; Malik, M.A.; Qi, Z.; Huang, B.T.; Li, Q.; Sarkar, M. Influence of the PVA fibers and $\mathrm{SiO}_{2} \mathrm{NPs}_{\text {on }}$ the structural properties of fly ash based sustainable geopolymer. Constr. Build. Mater. 2018, 164, 238-245. [CrossRef]

66. Wan, X.; Shen, C.; Wang, P.; Zhao, T.; Lua, Y. A study on fracture toughness of ultra-high toughness geopolymer composites based on Double-K Criterion. Constr. Build. Mater. 2020, 251, 118851. [CrossRef]

67. Zhang, P.; Wang, K.; Wang, J.; Guo, J.; Hua, S.; Ling, Y. Mechanical properties and prediction of fracture parameters of geopolymer/alkali-activated mortar modified with PVA fiber and nano-SiO 2 . Ceram. Int. 2020, 46, 20027-20037. [CrossRef]

68. Kan, L.L.; Wang, W.S.; Liu, W.D.; Wu, M. Development and characterization of fly ash based PVA fiber reinforced Engineered Geopolymer Composites incorporating metakaolin. Cem. Concr. Compos. 2020, 108, 103521. [CrossRef]

69. Kan, L.; Zhang, L.; Zhao, Y.; Wu, M. Properties of polyvinyl alcohol fiber reinforced fly ash based Engineered Geopolymer Composites with zeolite replacement. Constr. Build. Mater. 2020, 231, 117161. [CrossRef]

70. Malik, M.A.; Sarkar, M.; Xu, S.; Li, Q. Effect of PVA/SiO 2 NPs additive on the structural, durability, and fire resistance properties of geopolymers. Appl. Sci. 2019, 9, 1953. [CrossRef]

71. Al-Majidi, M.H.; Lampropoulos, A.; Cundy, A.B.; Tsioulou, O.T.; Al-Rekabi, S. A novel corrosion resistant repair technique for existing reinforced concrete $(\mathrm{RC})$ elements using polyvinyl alcohol fibre reinforced geopolymer concrete (PVAFRGC). Constr. Build. Mater. 2018, 164, 603-619. [CrossRef]

72. Okada, K.; Imase, A.; Isobe, T.; Nakajima, A. Capillary rise properties of porous geopolymers prepared by an extrusion method using polylactic acid (PLA) fibers as the pore formers. J. Eur. Ceram. Soc. 2011, 31, 461-467. [CrossRef]

73. Rasouli, H.R.; Golestani-Fard, F.; Mirhabibi, A.R.; Nasab, G.M.; MacKenzie, K.J.D.; Shahraki, M.H. Fabrication and properties of microporous metakaolin-based geopolymer bodies with polylacticacid (PLA) fibers as pore generators. Ceram. Int. 2015, 41, 7872-7880. [CrossRef]

74. Asrani, N.P.; Murali, G.; Parthiban, K.; Surya, K.; Prakash, A.; Rathika, K.; Chandru, U. A feasibility of enhancing the impact resistance of hybrid fibrous geopolymer composites: Experiments and modelling. Constr. Build. Mater. 2019, 203, 56-68. [CrossRef]

75. Wang, Y.; Aslani, F.; Valizadeh, A. An investigation into the mechanical behaviour of fibre-reinforced geopolymer concrete incorporating NiTi shape memory alloy, steel and polypropylene fibres. Constr. Build. Mater. 2020, 259, 119765. [CrossRef]

76. Asrani, N.P.; Murali, G.; Abdelgader, H.S.; Parthiban, K.; Haridharan, M.K.; Karthikeyan, K. Investigation on mode I fracture behavior of hybrid fiber-reinforced geopolymer composites. Arab. J. Sci. Eng. 2019, 44, 8545-8555. [CrossRef]

77. Goncalves, J.R.A.; Boluk, Y.; Bindiganavile, V. Crack growth resistance in fibre reinforced alkali-activated fly ash concrete exposed to extreme temperatures. Mater. Struct. 2018, 51, 42. [CrossRef]

78. Bindiganavile, V.; Goncalves, J.R.A.; Boluk, Y. Crack growth resistance in fibre reinforced geopolymer concrete exposed to sustained extreme temperatures. Key Eng. Mat. 2016, 711, 511-518. [CrossRef]

79. Ganesh, C.; Muthukannan, M. Experimental study on the behaviour of hybrid fiber reinforced geopolymer concrete under ambient curing condition. IOP Conf. Ser. Mater. Sci. Eng. 2019, 561, 012014. [CrossRef]

80. Moradikhou, A.B.; Esparham, A.; Avanaki, M.J. Physical \& mechanical properties of fiber reinforced metakaolin-based geopolymer concrete. Constr. Build. Mater. 2020, 251, 118965.

81. Khan, M.Z.N.; Hao, Y.; Hao, H.; Shaikh, F.U.A. Mechanical properties of ambient cured high strength hybrid steel and synthetic fibers reinforced geopolymer composites. Cem. Concr. Compos. 2018, 85, 133-152. [CrossRef] 
82. Khan, M.Z.N.; Hao, Y.; Hao, H.; Shaikha, F.U.A. Mechanical properties and behaviour of high-strength plain and hybrid-fiber reinforced geopolymer composites under dynamic splitting tension. Cem. Concr. Compos. 2019, 104, 103343. [CrossRef]

83. Khan, M.Z.N.; Hao, Y.; Hao, H.; Shaikh, F.U.A.; Liu, K. Mechanical properties of ambient cured high-strength plain and hybrid fiber reinforced geopolymer composites from triaxial compressive tests. Constr. Build. Mater. 2018, 185, 338-353. [CrossRef]

84. Khan, M.Z.N.; Hao, Y.; Hao, H.; Shaikh, F.U.A. Experimental evaluation of quasi-static and dynamic compressive properties of ambient-cured high-strength plain and fiber reinforced geopolymer composites. Constr. Build. Mater. 2018, 166, 482-499. [CrossRef]

85. Alrefaei, Y.; Dai, J.G. Tensile behavior and microstructure of hybrid fiber ambient cured one-part engineered geopolymer composites. Constr. Build. Mater. 2018, 184, 419-431. [CrossRef]

86. Cui, Y.; Hao, H.; Li, J.; Chen, W. Effect of adding methylcellulose on mechanical and vibration properties of geopolymer paste and hybrid fiber-reinforced geopolymer composite. J. Mater. Civ. Eng. 2020, 32, 04020166. [CrossRef]

87. Yang, T.; Han, E.; Wang, X.; Wu, D. Surface decoration of polyimide fiber with carbon nanotubes and its application for mechanical enhancement of phosphoric acid-based geopolymers. Appl. Surf. Sci. 2017, 416, 200-212. [CrossRef]

88. Derombise, G.; Van Schoors, L.V.; Davies, P. Degradation of Technora aramid fibres in alkaline and neutral environments. Polym. Degrad. Stab. 2009, 94, 1615-1620. [CrossRef]

89. Yao, J.; Bastiaansen, C.W.M.; Peijs, T. High strength and high modulus electrospun nanofibers. Fibers 2014, 2, 158-187. [CrossRef]

90. Kuciel, S.; Kuźniar, P.; Jakubowska, P. Properties of composites based on polyamide 10.10 reinforced with carbon fibers. Polimery 2016, 61, 106-112. [CrossRef]

91. Rashad, A.M. The effect of polypropylene, polyvinyl-alcohol, carbon and glass fibres on geopolymers properties. Mater. Sci. Technol. 2019, 35, 127-146. [CrossRef]

92. Bhutta, A.; Farooq, M.; Zanotti, C.; Banthia, N. Pull-out behavior of different fibers in geopolymer mortars: Effects of alkaline solution concentration and curing. Mater. Struct. 2017, 50, 80. [CrossRef]

93. Mierzwiński, D.; Korniejenko, K.; Łach, M.; Mikuła, J.; Krzywda, J. Effect of coffee grounds addition on efflorescence in fly ash-based geopolymer. IOP Conf. Ser. Mater. Sci. Eng. 2018, 416, 012035. [CrossRef]

94. Maras, M.M.; Kose, M.M. Mechanical and microstructural properties of polypropylene fiber-reinforced geopolymer composites. J. Fiber Sci. Technol. 2019, 75, 35-46. [CrossRef]

95. Bumanis, G.; Vitola, L.; Pundiene, I.; Sinka, M.; Bajare, D. Gypsum, Geopolymers, and starch-Alternative binders for bio-based building materials: A review and life-cycle assessment. Sustainability 2020, 12, 5666. [CrossRef]

96. Kinnunen, P.; Ismailov, A.; Solismaa, S.; Sreenivasan, H.; Raisanen, M.L.; Levanen, E.; Illikainen, M. Recycling mine tailings in chemically bonded ceramics-A review. J. Clean. Prod. 2018, 174, 634-649. [CrossRef]

97. Korniejenko, K.; Mucsi, G.; Halyag, N.P.; Szabó, R.; Mierzwiński, D.; Louda, P. Mechanical properties of basalt fiber reinforced fly ash-based geopolymer composites. KnE Eng. 2020, 2020, 86-100. [CrossRef]

98. Palomo, A.; Krivenko, P.; Garcia-Lodeiro, I.; Kavalerova, E.; Maltseva, O.; Fernández-Jiménez, A. A review on alkaline activation: New analytical perspectives. Mater. Constr. 2014, 64, 315. [CrossRef]

99. Korniejenko, K.; Łach, M.; Chou, S.-Y.; Lin, W.-T.; Cheng, A.; Hebdowska-Krupa, M.; Gądek, S.; Mikuła, J. Mechanical properties of short fiber-reinforced geopolymers made by casted and 3D printing methods: A comparative study. Materials 2020, 13, 579. [CrossRef]

100. Kidalova, L.; Stevulova, N.; Terpakova, E.; Sicakova, A. Utilization of alternative materials in lightweight composites. J. Clean. Prod. 2012, 34, 116-119. [CrossRef]

(C) 2020 by the authors. Licensee MDPI, Basel, Switzerland. This article is an open access article distributed under the terms and conditions of the Creative Commons Attribution (CC BY) license (http://creativecommons.org/licenses/by/4.0/). 